University of Chicago Law School

Chicago Unbound

Journal Articles

Faculty Scholarship

1977

\title{
Antitrust Liability for Attempts to Influence Government Action: The Basis and Limits of the Noerr--Pennington Doctrine
}

Daniel R. Fischel

Follow this and additional works at: https://chicagounbound.uchicago.edu/journal_articles

Part of the Law Commons

\section{Recommended Citation}

Daniel R. Fischel, "Antitrust Liability for Attempts to Influence Government Action: The Basis and Limits of the Noerr--Pennington Doctrine," 45 University of Chicago Law Review 80 (1977).

This Article is brought to you for free and open access by the Faculty Scholarship at Chicago Unbound. It has been accepted for inclusion in Journal Articles by an authorized administrator of Chicago Unbound. For more information, please contact unbound@law.uchicago.edu. 


\title{
Antitrust Liability for Attempts to Influence Government Action: The Basis and Limits of the Noerr-Pennington Doctrine
}

\author{
Daniel R. Fischel $\dagger$
}

With government regulation of the economy proliferating, courts increasingly face the question whether private parties can jointly attempt to attain anticompetitive ends by petitioning the government without violating the Sherman Act.' Adverse effects on competition may result from the petitioning activity itself or from the government action sought. While the broad language of the Act ${ }^{2}$ could be construed to prohibit all such joint efforts as "combination[s] . . . in restraint of trade," the Supreme Court has rejected this interpretation. ${ }^{3}$ The extent to which attempts to influence the government are exempt from the antitrust laws is determined by the Noerr-Pennington doctrine, a shorthand description of the seminal Supreme Court cases in this area. The precise basis and limits of this exemption from the antitrust laws, however, have yet to be unequivocally articulated.

Establishing the scope of this exemption has proven difficult largely because of the variety of governmental institutions whose decisions affect private economic interests and the diverse means that private parties utilize in attempting to influence these institutions. Private anticompetitive ends may be sought, for example, by lobbying the legislature to enact a statute, ${ }^{4}$ petitioning the executive to enforce a law in a certain manner, ${ }^{5}$ opposing the grant of a license

$\dagger$ J.D., The University of Chicago, 1977. The author would like to thank Professors Richard Posner, Kenneth Dam, and Geoffrey Stone, who read and helpfully criticized earlier drafts of this article.

' Section 1 of the Sherman Ast, 15 U.S.C. $§ 1$ (1970), prohibits "[e]very contract, combination in the form of trust or otherwise, or conspiracy" in restraint of trade. Section 2 proscribes all attempts and conspiracies to monopolize. While the problems addressed in this article typically arise when competitors jointly attempt to influence governmental decisionmaking, the analysis is equally applicable to attempts by single firms, which may be held liable under $\$ 2$ of the Sherman Act.

2 The language of the Sherman Act was deliberately drafted in broad terms because it was felt that particularization might defeat its purpose "by providing loopholes for escape." Appalachian Coals v. United States, 288 U.S. 344, 359-60 (1932), quoted in Cantor v. Detroit Edison Co., 428 U.S. 579, 599 n.40 (1976).

3 Eastern R.R. Presidents Conference v. Noerr Motor Freight, Inc., 365 U.S. 127, 136 (1960).

+ E.g., Eastern R.R. Presidents Conference v. Noerr Motor Freight, Inc., 365 U.S. 127 (1960).

s E.g., United Mine Workers v. Pennington, 381 U.S. 657 (1965). 
by an administrative body to a competitor, ${ }^{6}$ bringing a lawsuit against a competitor to reduce competition, ${ }^{7}$ or urging a governmental unit not to purchase the goods of a competitor. ${ }^{8}$ Moreover, the methods employed by private parties to influence governmental action may not be limited to truthful dissemination of information but may also include deliberate misrepresentations, ${ }^{9}$ illegal campaign contributions, ${ }^{10}$ threats, ${ }^{11}$ extortion, or bribery. ${ }^{12}$ This variety complicates the task of ascertaining the scope of the Noerr-Pennington doctrine because some but not all of these attempts to influence the government will be protected by the right to petition embodied in the first amendment, a right whose boundaries remain uncertain. ${ }^{13}$

Part I of this article will discuss the evolution and present status of the Noerr-Pennington doctrine in the Supreme Court. The basis and limits of the doctrine will be analyzed in Part II. It will be argued that the exemption from the antitrust laws established by the Noerr-Pennington line of cases is properly limited to activity protected by the constitutional right to petition. General principles for determining whether anticompetitive attempts to influence the government are constitutionally protected will be proposed. Applying these principles, Part III will analyze the "sham" exception to the Noerr exemption, and Part IV will discuss a miscellany of questions regarding the doctrine that have arisen in the courts.

An important point, but one that is easily lost sight of, is that the Noerr-Pennington line of cases concerns the scope of an exemption from the antitrust laws. It must be emphasized at the outset

- E.g., California Motor Trans. Co. v. Trucking Unlimited, 404 U.S. 508 (1972).

' E.g., Walker Process Equip., Inc. v. Food Mach. \& Chem. Corp., 382 U.S. 172 (1965).

" E.g., George R. Whitten, Jr., Inc. v. Paddock Pool Builders, Inc., 424 F.2d 25 (1st Cir.), cert. denied, 400 U.S. 850 (1970).

- E.g., Metro Cable Co. v. CATV of Rockford, Inc., 516 F.2d 220 (7th Cir. 1975); Woods Exploration \& Producing Co. v. Aluminum Co. of America, 438 F.2d 1286 (5th Cir. 1971), cert. denied, 404 U.S. 1047 (1972).

10 E.g., Cow Palace, Ltd. v. Associated Milk Producers, Inc., 390 F. Supp. 696 (D. Colo. 1975).

" E.g., Sacramento Coca-Cola Bottling Co. v. Teamsters Local 150, 440 F.2d 1096 (9th Cir.), cert. denied, 404 U.S. 826 (1971). 1975).

${ }_{12}$ E.g., Cow Palace, Ltd. v. Associated Milk Producers, Inc., 390 F. Supp. 696 (D. Colo.

13 It was not by accident or coincidence that the rights to freedom in speech and press were coupled in a single guaranty with the rights of the people peaceably to assemble and to petition for redress of grievances. All these, though not identical, are inseparable. They are cognate rights . . . and therefore are united in the First Article's assurance.

Thomas v. Collins, 323 U.S. 516, 530 (1945). The Court has never specifically and separately defined the scope of the right to petition. See Annot., 30 L. Ed. 2d 914 (1972). 
that conduct unprotected by Noerr does not necessarily constitute an antitrust violation. ${ }^{14}$

\section{The Noerr-Pennington Doctrine in the Supreme Court}

A. Development of the Doctrine

1. Attempts to Influence Legislative Decisions. The Supreme Court first considered the interplay between attempts to influence governmental action and the antitrust laws in Eastern Railroad Presidents Conference v. Noerr Motor Freight, Inc. ${ }^{15}$ Noerr was the culmination of a three-decade competitive struggle between railroads and truckers in Pennsylvania. In an attempt to improve their competitive position, the railroads began a widespread publicity campaign, directed by a public relations firm, against the trucking industry. Front organizations supported by the railroads vilified the truckers. By use of this "third-party technique," the participation of the railroads in the campaign against the trucking industry was hidden from the public.

The campaign was highly successful. Not only was adverse public opinion generated against the truckers but a bill which would have increased the permissible weight limits on highways, thereby improving the competitive position of the truckers, was vetoed by the governor of Pennsylvania. The truckers responded by filing an antitrust action against the railroads. The district court ${ }^{16}$ found that the activities of the railroads were fraudulent, malicious, and violative of the antitrust laws. The Third Circuit affirmed. ${ }^{17}$

In a unanimous opinion by Justice Black, the Supreme Court reversed, holding that joint attempts to influence the passage or enforcement of laws are exempt from the Sherman Act. Four arguments were advanced to support this ruling. First, the Court emphasized the "essential dissimilarity" 18 between an agreement to lobby for legislation and the agreements traditionally condemned by the

is This point is forcefully illustrated by two cases involving the same parties. In George R. Whitten, Jr., Inc. v. Paddock Pool Builders, Inc., 424 F.2d 25 (1st Cir.) cert. denied, 400 U.S. 850 (1970), the First Circuit held that an attempt to influence government purchases was not exempted from the antitrust laws by Noerr. See text and notes at notes 187-188 infra. In a later case, however, the First Circuit held that defendant's conduct, even if unprotected by Noerr, was unfair competition which did not rise to the level of an antitrust violation. George R. Whitten, Jr., Inc. v. Paddock Pool Builders, Inc., 508 F.2d 547 (1st Cir. 1974), cert. denied, 421 U.S. 1004 (1975). The relationship between business torts and the antitrust laws is beyond the scope of this article.

is 365 U.S. 127 (1965).

1s 155 F. Supp. 768 (E.D. Pa. 1957).

17273 F.2d 218 (3d Cir. 1959).

I* 365 U.S. 127, 136 (1960). 
Sherman Act, such as price-fixing and boycotts. The dissimilarity, while not "conclusive" on the question of the antitrust laws' applicability, was a "warning" against treating joint lobbying efforts as an unlawful restraint. ${ }^{19}$ Second, the Court stressed that prohibiting joint lobbying efforts would substantially impair the ability of the people to make their wishes known to public officials, ${ }^{20}$ thus impeding the proper functioning of our democracy. ${ }^{21}$ Moreover, applying the antitrust laws to lobbying efforts "would impute to the Sherman Act a purpose to regulate, not a business activity, but political activity ... ."22 Finally, construing the Sherman Act to reach lobbying activities "would raise important constitutional questions" ${ }^{\prime 23}$ because the right to petition the government is protected by the first amendment. In a footnote, however, the Court stated that it was unnecessary to decide whether the railroad's activities were protected by the first amendment. ${ }^{24}$

The Court's reasoning in Noerr is not persuasive. The essential dissimilarity argument, suggesting that atypical, untraditional, anticompetitive agreements are not violative of the antitrust laws, is contrary to prevailing precedent. ${ }^{25}$ On other occasions, moreover, the Court has held the use of the courts to achieve anticompetitive ends can violate the antitrust laws, although such conduct is "essentially dissimilar" to practices traditionally condemned by the antitrust laws. ${ }^{26}$ The "representative government" argument-that the Sherman Act regulates business rather than political activity-merely restates the essential dissimilarity argument, which

Id. at 137 .

Id.

${ }^{21}$ In Parker v. Brown, 317 U.S. 341 (1943), the Court held that the Sherman Act was not intended to apply to state action. This state action exemption from the antitrust laws has been narrowed by recent decisions. See Cantor v. Detroit Edison Co., 428 U.S. 579 (1976); Goldfarb v. Virginia State Bar, 421 U.S. 773 (1975). For a discussion of the relationship between Cantor and Noerr, see text and notes at notes 69-75 infra.

22365 U.S. 127, 137 (1960).

${ }^{23}$ Id. at 138.

2s Id. at 132 n.6.

${ }^{25}$ See, e.g., American Tobacco Co. v. United States, 328 U.S. 781, 809 (1946) (It is not the form of combination or the particular means used but the result which is condemned by the antitrust laws); United States v. American Tobacco Co., 221 U.S. 106, 181 (1911) (Sherman Act encompasses all acts within its spirit or purpose "without regard to the garb in which such acts were clothed.").

2 E.g., Walker Process Equip., Inc. v. Food Mach. \& Chem. Corp., 382 U.S. 172 (1965); Kobe, Inc. v. Dempsey Pump Co., 198 F.2d 416 (10th Cir.), cert. denied, 344 U.S. 837 (1952). In the most recent major case dealing with the Noerr-Pennington doctrine, the Court has seemingly abandoned the "essential dissimilarity" rationale and has focused exclusively on the constitutional underpinnings of Noerr. See California Motor Trans. Co. v. Trucking Unlimited, 404 U.S. 508 (1972). 
supposedly was not conclusive. ${ }^{27}$ Nor did the Court explain how either the right of private parties to inform their representatives or the ability of government officials to take action restraining trade would be impaired by the imposition of sanctions against the deceptive and fraudulent conduct of the railroads.

The final reason offered by the Noerr Court, an unwillingness to "lightly impute to Congress" 28 an intent to prohibit activity arguably protected by the first amendment, is based on an unduly narrow view of the Sherman Act. The Act, for example, has been applied to prohibit the bringing of certain lawsuits, ${ }^{29}$ even though access to the courts is guaranteed by the first amendment. ${ }^{30}$ The Court, moreover, has repeatedly stated in other contexts that Congress in enacting the Sherman Act left none of its constitutional power unexercised. ${ }^{31}$ If the lobbying techniques of the railroads were unprotected by the first amendment, an exemption from the antitrust laws was not warranted. Yet, it was precisely the constitutional question which the Court refused to decide in Noerr even though the first three grounds advanced for the Court's decision were inconclusive. ${ }^{32}$

${ }^{27}$ Note, 57 Calif. L. Rev. 518, 526 (1969); Note, 33 Rocky Mr. L. Rev. 413, 415 (1961).

Moreover, it is not clear that the present Supreme Court would draw such a bright line between political and business activity. Several lower courts, for example, relying on the language in Noerr that the Sherman Act was only intended to regulate business activity, created a learned profession exemption to the antitrust laws. E.g., Marjorie Webster Junior College, Inc., v. Middle States Ass'n of Colleges and Secondary Schools, Inc., 432 F.2d 650, 654 (D.C. Cir.), cert. denied, 400 U.S. 965 (1970). In Goldfarb v. Virginia State Bar, 421 U.S. 773 (1975), the Court rejected this limitation on the scope of the Sherman Act.

2x 365 U.S. at 138.

2 See, e.g., Walker Process Equip., Inc. v. Food Mach. \& Chem. Corp., 382 U.S. 172 (1965); Kobe, Inc. v. Dempsey Pump Co., 198 F.2d 416 (10th Cir.), cert. denied, 344 U.S. 837 (1952).

${ }^{30}$ E.g., California Motor Transp. Co. v. Trucking Unlimited, 404 U.S. 508 (1972); NAACP v. Button, 371 U.S. 415 (1963).

No one has ever contended that the antitrust laws cannot be applied to conduct that involves speech. As the Supreme Cnurt in Giboney v. Empire Storage \& Ice Co., 336 U.S. 490 (1949), has stated: "Such an expansive interpretation of the constitutional guarantees of speech and press would make it practically impossible ever to enforce laws against agreements in restraint of trade as well as many other agreements and conspiracies deemed injurious to society." Id. at 502 . For an early suggestion that condemning certain agreements under the antitrust laws might infringe freedom of speech, see American Column Co. v. United States, 257 U.S. 377, 413 (1921) (Holmes, J., dissenting).

${ }^{31}$ E.g., United States v. Frankfort Distilleries, Inc., 324 U.S. 293, 298 (1945); Apex Hosiery Co. v. Leader, 310 U.S. 469, 495 (1940).

32 Later decisions, however, have viewed Noerr as a first amendment decision. E.g., - Buckley v. Valeo, 424 U.S. 1, 49 (1976); California Motor Transp. Co. v. Trucking Unlimited, 404 U.S. 508, 509-10 (1972). Similarly, some commentators have erroneously asserted that Noerr held that lobbying activities were protected by the first amendment. See, e.g., Note, 62 Cornell L. Rev. 628, 637-38 (1977). 
2. The Extension of Noerr to Attempts to Influence Executive Action. Noerr held that attempts to influence the passage or enforcement of laws are exempt from the Sherman Act. The Noerr Court's reasoning suggested that only political activity is exempted. In United Mine Workers $v$. Pennington, ${ }^{33}$ the Court apparently abandoned this limitation on the Noerr doctrine. In Pennington, several large mine operators, in cooperation with union officials, attempted to eliminate the competition of smaller coal producers by persuading the Secretary of Labor to set a higher minimum wage for employees of producers selling to the TVA under the WalshHealey Act ${ }^{34}$ and by convincing the TVA to purchase coal only from producers covered by the higher minimum wage provision. The $\mathrm{Su}-$ preme Court found this activity protected by Noerr: "Joint efforts to influence public officials do not violate the antitrust laws even though intended to eliminate competition. Such conduct is not illegal, either standing alone or as part of a broader scheme itself violative of the Sherman Act." 35

The Pennington opinion is troublesome in several respects. As in Noerr, the Court did not determine whether the defendants' immunity from antitrust liability was predicated on the first amendment or construction of the Sherman Act. A second troubling aspect of Pennington is that it apparently extends Noerr to attempts to influence government officials performing purely commercial functions. Exempting the defendants' concerted action to persuade the Secretary of Labor to set a higher minimum wage from the antitrust laws was clearly consistent with the rationale of Noerr because the Walsh-Healey Act conferred discretion on the Secretary to set wage levels. The policymaking role of the TVA was less obvious. If the TVA made its purchasing decisions to further policy objectives such as supporting the Secretary's minimum wage policies or fostering regional development, then exempting the defendants' lobbying of the TVA was warranted by Noerr. If, however, the TVA made its purchasing decisions on purely economic grounds without regard to policy considerations, Pennington was a considerable extension of Noerr. The Court, however, failed to examine the nature of the TVA's decision or contrast it with the political decisions lobbied for in Noerr. This failure, coupled with the Court's broad statement of the Noerr exemption, could be interpreted as broadening Noerr to encompass attempts to influence purely com-

381 U.S. 657 (1965).

ม 41 U.S.C. $\$ \$ 35-45$ (1970).

s5 381 U.S. 657,670 (1965). 
mercial government action.

The Court's lack of sensitivity to the possible absence of political activity in Pennington is particularly surprising in light of Continental Ore Co. $v$. Union Carbide \& Carbon Corp. ${ }^{36}$ decided between Noerr and Pennington. In Continental Ore the plaintiff vanadium producer alleged that an American vanadium producer and its subsidiary, which served as the wartime purchaser of vanadium products for the Canadian government, conspired with another American producer to eliminate plaintiff from the Canadian market. Defendants argued that their activities were protected by Noerr because the subsidiary was acting as purchasing agent for the Canadian government. ${ }^{37}$ The Court refused, however, to apply or extend Noerr because the alleged conspiracy involved "private commercial activity, no element of which involved seeking to procure the passage or enforcement of laws." 38

The broad language of Pennington is inconsistent with Continental Ore. It is unlikely, however, that the Court in Pennington meant to reject both the limiting language of Noerr and the Continental Ore decision in a case dealing primarily with other issues. ${ }^{39}$ Nevertheless, the Supreme Court's failure in Noerr, and particularly in Pennington, to indicate the limits of the antitrust exemption for attempts to influence governmental action has understandably confused the lower courts. ${ }^{40}$

3. The Extension of Noerr to Attempts to Influence Adjudicative Bodies. In California Motor Transport Co. v. Trucking Unlimited, ${ }^{41}$ the Court extended the Noerr exemption to concerted attempts to influence the courts and administrative adjudicative bodies. California Motor Transport was a suit for treble damages and injunctive relief brought by fourteen plaintiffs against nineteen defendants, all motor carriers subject to regulation by the California Public Utilities Commission. The complaint alleged that defendants had conspired to monopolize trade in the transportation of goods by instituting state and federal administrative and judicial proceedings in opposition to applications by plaintiffs to acquire motor carrier operating rights in California. These proceedings were

370 U.S. 690 (1962).

${ }^{37}$ Continental Ore attached no significance to the fact that a foreign government was involved. On the relationship between Noerr and attempts to influence foreign governments, see text and notes at notes 202-207 infra.

370 U.S. at 707.

The Court was primarily concerned with the labor exemption from the antitrust laws.

to See text and notes at notes 171-211 infra.

1404 U.S. 508 (1972). 
instituted "with or without probable cause, and regardless of the merits of the cases." 42

After the holding of Pennington that attempts to influence public officials were exempt from the Sherman Act, it might have appeared a foregone conclusion that the defendants' activities in California Motor Transport were also exempt. Yet the extent to which courts and adjudicative bodies could legally be utilized to attain anticompetitive ends after Pennington was far from clear. On the one hand, several Supreme Court ${ }^{43}$ and lower court ${ }^{44}$ cases had held that bringing a patent infringement suit could in certain circumstances constitute an antitrust violation. On the other hand, the Court's holding in NAACP v. Button ${ }^{45}$ that a state could not prevent the NAACP from providing free counsel for school desegregation suits consistently with the first amendment suggested that there might be a constitutional right to jointly petition the courts. Further, the impact of Noerr itself was ambiguous. Attempts to influence the courts, a coordinate branch of government, might appear to enjoy the same exemption from the antitrust laws as similar conduct directed toward the other branches of government. But it could be argued that attempts to influence the courts are not protected by Noerr because courts, unlike the legislature or executive, do not make or enforce laws but only apply laws and policies established by other branches of government. ${ }^{46}$

Without discussing the conflicting precedents, Justice Douglas, writing for a majority of the Court ${ }^{47}$ quickly dismissed the contention that the Noerr-Pennington doctrine was inapplicable to attempts to influence adjudication:

We conclude that it would be destructive of rights of association and petition to hold that groups with common interests may not, without violating the antitrust laws, use the channels and procedures of state and federal agencies and courts to advocate their causes and points of view respecting resolution of

42 Id. at 512 .

${ }^{13}$ Walker Process Equip., Inc. v. Food Mach. \& Chem. Corp., 382 U.S. 172 (1965); United States v. Singer Mfg. Co., 374 U.S. 174 (1963).

" E.g., Kobe, Inc. v. Dempsey Pump Co., 198 F.2d 416 (10th Cir.), cert. denied, 344 U.S. 837 (1952); Lynch v. Magnavox Co., 94 F.2d 883 (9th Cir. 1938).

is 371 U.S. 415 (1963).

${ }^{16}$ E.g., Trucking Unlimited v. California Motor Transp. Co., 432 F.2d 755, 758 (9th Cir. 1970), aff'd on other grounds, 404 U.S. 508 (1972).

"Justices Stewart and Brennan concurred in the judgment. Justices Powell and Rehnquist did not participate. 
their business and economic interests vis-a-vis their competitor. ${ }^{48}$

The California Motor Transport Court squarely rested its decision on the first amendment. The Court did not, however, decide whether the Noerr-Pennington exemption is applicable only to conduct protected by the first amendment.

While California Motor Transport can therefore be viewed as an extension of first amendment protection to certain petitioning conduct in the adjudicative context, there is language in the opinion signaling a retreat from Noerr. Particularly troublesome is a paragraph of the opinion in which Justice Douglas discussed the relationship between the first amendment and the antitrust laws: "Petitioners, of course, have the right of access to the agencies and courts . . . . That right, as indicated, is part of the right of petition protected by the First Amendment. Yet that does not necessarilly give them immunity from the antitrust laws." 99 This language is impossible to reconcile with the statement earlier in the Court's opinion that petitioning the courts, even with an anticompetitive purpose, is protected by the first amendment. ${ }^{50}$ Moreover, this aspect of California Motor Transport is also flatly inconsistent with Noerr, which held that lobbying is exempt from the antitrust laws. As Justice Stewart stated in his concurring opinion: "Today the Court retreats from Noerr, and in the process tramples upon important First Amendment values . . . . [Noerr] explicitly held . . . that the joint exercise of the constitutional right of petition is given immunity from the antitrust laws." 51

It is unlikely, however, that Justice Douglas intended to limit Noerr in a case where the Court extended Noerr to attempts to influence adjudicatory bodies. Nor have subsequent cases interpreted California Motor Transport as limiting Noerr. Nevertheless, it is conceivable that future cases could seize on ambiguous language in California Motor Transport as a rationale for narrowing the Noerr-Pennington doctrine.

\section{B. Present Vitality of the Doctrine}

While California Motor Transport is the last major Supreme Court case to interpret the Noerr-Pennington doctrine, the doc-

\footnotetext{
${ }^{4 x} 404$ U.S. 508, 510-11 (1972).

Id. at 513 .

so $I d$. at $510-11$.

I Id. at 516-17.
} 
trine's continued vitality has been called into question by the recent case of Cantor $v$. Detroit Edison Co. ${ }^{52}$

1. Cantor v. Detroit Edison Co. Detroit Edison, a private utility pervasively regulated by the Michigan Public Service Commission, has long been the sole supplier of electricity in southeastern Michigan. The utility also furnished its residential customers with free light bulbs. This practice, begun long before state regulation of electric utilities had become part of the utility's rate structure, could not be changed unless a new tariff was filed with and approved by the Commission. Cantor, a retail druggist who sold light bulbs, brought an antitrust action against Detroit Edison, alleging that Edison was using its monopoly power in the distribution of electricity to restrain competition in the light bulb market. Relying on Parker v. Brown, ${ }^{53}$ in which the Supreme Court held that a stateimposed monopoly was beyond the reach of the Sherman Act, the district court ${ }^{54}$ and the Sixth Circuit ${ }^{55}$ both held that the Commission's approval of the tariff was sufficient state action to exempt the light bulb program.

The Supreme Court reversed. Mr. Justice Stevens delivered the opinion of the Court, and five Justices joined in Parts I and III of his opinion, the parts most relevant to Noerr. ${ }^{56}$ In Part I, Justice Stevens noted that while the light bulb program was regulated, the primary function of the Commission was to regulate electricity and neither the Michigan legislature nor the Commission had ever specifically investigated the utility's practice of furnishing light bulbs to its residential customers. Therefore, the opinion reasoned, the state's policy was "neutral" regarding the desirability of Detroit Edison's light bulb program. ${ }^{57}$

In Part III, Justice Stevens discussed the two possible justifications for exempting private conduct regulated by state law from the Sherman Act: (1) that it would be unjust to subject to antitrust

32428 U.S. 579 (1976).

33317 U.S. 341 (1942).

st 392 F. Supp. 1110 (E.D. Mich. 1974), aff'd, 513 F.2d 630 (6th Cir. 1975), rev'd, 428 U.S. 579 (1976).

ت5 513 F.2d 630 (6th Cir. 1975), rev'd, 428 U.S. 579 (1976).

ss Only four justices joined in the other two parts of Stevens' opinion. In Part II, Justice Stevens stated that the state action exemption of Parker $v$. Brown was limited to official action taken by state officials. As Detroit Edison was not a state official, Parker was found inapposite. 428 U.S. at 589-92. In the final part of his opinion, Justice Stevens rejected Detroit Edison's claim that imposition of antitrust liability would be unjust because the utility had justifiably understood prior precedents to hold regulated conduct to be immune from antitrust liability and state regulation had increased the company's risk of violating the antitrust laws. Id. at 598-603.

Ir 428 U.S. at 584. 
liability a private citizen who has done nothing but obey the state's command; and (2) that Congress did not intend to superimpose the antitrust laws as an additional, and perhaps conflicting, regulatory mechanism in areas regulated by state law. The unfairness justification was dismissed because the light bulb program was initiated years before the regulatory agency was created and the option to continue the light bulb program belonged primarily to Detroit Edison, not the Commission. Thus, the facts in Cantor were similar to other cases involving "a blend of private and public decisionmaking," 58 where "notwithstanding the state participation in the decision, the private party exercised sufficient freedom of choice to enable the Court to conclude that he should be held responsible for the consequences of his decision." 59

The second possible ground for immunizing private conduct required by state law-that Congress did not intend to impose antitrust standards on conduct already regulated by state law-was also rejected, for three reasons. First, the Court stressed that concurrent federal and state regulation did not necessarily mean that private conduct would be governed by inconsistent standards. Indeed, there was no necessary conflict between state regulation of the natural monopoly of electricity distribution and federal regulation of the competitive market in light bulbs. ${ }^{60}$ Second, federal interests should not automatically be subordinated to those of the states when state regulations and federal antitrust law conflict. A state regulation should give rise to an antitrust exemption only if "necessary in order to make the regulatory act work." ${ }_{11}$ Since Michigan's regulation of electricity was not dependent on regulation of the light bulb program, federal interests predominated. Finally, the Court stated that even if Congress did not intend the antitrust laws to apply to areas pervasively regulated by a state, the antitrust laws could still oper-

is Id. at 592 .

s9 Id. at 593 .

so Id. at 595-96.

${ }^{61}$ Id. at 597. This aspect of Cantor is significant because the Court for the first time applied the implied repeal doctrine, developed in precedents involving conflicts between federal regulation and federal antitrust policy, see, e.g., Gordon v. New York Stock Exch., 422 U.S. 659 (1975); Silver v. New York Stock Exch., 373 U.S. 341 (1963), to the situation where state regulation is arguably in conflict with federal antitrust policy. In cases of possible conflict between federal regulatory policy and federal antitrust policy, the Court has repeatedly stated that "[r]epeal [of the antitrust laws] is to be regarded as implied only if necessary to make the . . [ [Act] work, and even then only to the minimum extent necessary." 418 U.S. at 596 n. 34 (quoting Otter Tail Power Co. v. United States, 410 U.S. 366, 391 (1973), (quoting Silver v. New York Stock Exch., 373 U.S. 341, 352 (1963))). 
ate in essentially unregulated markets such as the light bulb market. $^{62}$

Chief Justice Burger and Justice Blackmun wrote concurring opinions. To the Chief Justice the key fact was the state's lack of "independent regulatory purpose" 63 in controlling the distribution of light bulbs. Justice Blackmun, concurring with the majority in the result only, fashioned a balancing test to determine when state programs are preempted by federal antitrust law. ${ }^{64}$ Justice Blackmun found Michigan's interest in regulating the distribution of light bulbs by utilities outweighed by the federal interest in promoting competition in the generally unregulated light bulb market. ${ }^{65}$

Mr. Justice Stewart, joined by Justices Powell and Rehnquist, filed a vigorous dissent. In their view, the Court's conclusion that it would not be unjust to impose antitrust liability on Detroit Edison because the utility participated in the decision to implement and continue the light bulb program "would effectively overrule . . . Noerr." ${ }^{\text {"66 }}$ Not only would the right to petition be penalized, but the effectiveness of state regulation would be severely hampered were regulatory bodies thus deprived of valuable sources of information. ${ }^{67}$ The dissent also criticized the Court's attempt to determine whether Congress intended to impose antitrust standards on conduct already regulated under state law. This process, said the dissent, represented no more than an ad hoc judgment of the substantive validity of state regulatory goals and was closely akin to the "discarded doctrine of substantive due process."68

2. The Impact of Cantor on the Noerr-Pennington Doctrine. It should be emphasized that the Noerr-Pennington doctrine was not briefed, argued, or at issue in Cantor. Noerr involved concerted lobbying activities, not private action taken in compliance with state law. ${ }^{69}$ Nevertheless, petitioning the government would be inhibited if antitrust liability could result from acting in compliance with the governmental action sought. Moreover, the broad language of the plurality opinion regarding the importance of "initiation" and

\footnotetext{
.2428 U.S. at 595.

n Id. at 604 .

a Id. at 605-14.

is Id. at 612-14.

"Id. at 616.

"Id. at 627 .

"Id.
}

"In many cases of attempts to influence the government, the issue of liability for acting in compliance with the governmental action sought will not arise. If, for example, a competitor succeeds in convincing an agency not to certify a new entrant, the competitor need take no further action. 
"freedom of choice" in determining the "fairness" of imposing antitrust liability lends plausibility to the dissent's view that Noerr has been eviscerated..$^{70}$

Other aspects of the Court's opinion, however, indicate that Noerr has not been significantly disturbed. Two crucial findings distinguish Cantor from the typical Noerr case in which exercise of the right to petition results in governmental action: (1) the light bulb program had existed long before the state regulatory scheme was enacted; and (2) the state had no policy concerning the desirability of the light bulb program. Bearing these findings in mind, Cantor should be narrowly interpreted to mean that a private party mày not shield himself from antitrust liability by having a regulatory body rubber-stamp a tariff which includes a report or a description of an anticompetitive activity. Thus, Cantor does not undercut Noerr, but rather represents a realistic assessment of the regulatory process. As the Court stated:

[N]othing in the Noerr opinion implies that the mere fact that a state regulatory agency may approve a proposal included in a tariff, and thereby require that the proposal be implemented until a revised tariff is filed and approved, is a sufficient reason for conferring antitrust immunity on the proposed conduct .... ${ }^{71}$

No exemption from the antitrust laws was appropriate in Cantor, therefore, because private commercial conduct is not transformed into state action by filing a tariff with an unsuspecting state regulatory agency. ${ }^{72} \mathrm{~A}$ different case would be presented, however, if a

${ }^{70}$ If the view of the dissent were correct, California Motor Transport would also be overruled, since a party who files a lawsuit or commences an agency proceeding has clearly taken the initiative.

11428 U.S. at 601-02.

72 This interpretation of Cantor is supported by the recent case of Bates v. State Bar, 97 S. Ct. 2691 (1977). In Bates, a disciplinary rule adopted by the state Supreme Court that prohibited advertising by attorneys was challenged as violative of the Sherman Act and the first amendment. The bar association contended that the disciplinary rules were exempt from the antitrust laws under the state action doctrine of Parker $v$. Brown. Plaintiffs, relying on Cantor, contended that no immunity was appropriate because the rules were derived from the Code of Professional Responsibility of the American Bar Association rather than from the unilateral action of state officials. The Court, however, refused to read Cantor so broadly, stating that the context in which the case arose was "crucial" to its understanding. Not only did Cantor involve a suit against a private party rather than state officials, but also the state had no independent regulatory interest in the light bulb market. Moreover, the light bulb program in Cantor was instigated by the utility with only the acquiescence of the state regulatory commission. The state disciplinary rules, by contrast, "reflect a clear articulation of the State's policy." $97 \mathrm{~S}$. Ct. at 2698. Having thus distinguished Cantor, the Court held that the disciplinary rules were exempt from the Sherman Act. The Court went on to hold the rules violative of the first amendment. 
private party instituted a particular practice only after it had been investigated and authorized by a state regulatory body. If, for example, both Cantor and Detroit Edison had filed briefs on the desirability of the light bulb program and the Commission had approved it in a contested proceeding, implementation of the program would likely be protected under Parker, even though Detroit Edison took the "initiative" in filing the tariff. ${ }^{73}$

The second tier of the Court's test in Cantor for determining when private conduct required by state law should be immune from antitrust liability-determining whether Congress intended to impose the antitrust laws as an additional regulatory mechanism in an area regulated by state law-also has implications for Noerr. While Justice Stevens apparently intended this test to come into play only when it would not be "unfair" to impose liability on a private party,$^{74}$ this qualification is unsound. If a non-essential aspect of a state regulatory scheme is repugnant to the Sherman Act, it should not be allowed to stand even if it would be unfair to impose liability on private parties complying with the state regulations. The unfairness in providing private parties with the choice of flouting state law or incurring antitrust liability could, as Justice Blackmun suggested, be substantially eliminated by recognizing compliance with state law as a defense to a treble damage action but not to a suit for injunctive relief. ${ }^{75}$ Exercise of the right to petition the government embodied in the Noerr-Pennington doctrine would not be substantially inhibited by the possibility that a court might enter an injunction against complying with state law. The possibility of federal preemption will, however, lessen to some degree the incentives to expend resources to achieve state action that restrains trade.

Read in context, therefore, Cantor does not significantly affect the Noerr-Pennington doctrine. Cantor deals with liability for

${ }^{73}$ As Justice Blackmun stated, basing antitrust liability on whether a state-sanctioned scheme was initiated by private actors rather than the state would be virtually impossible to apply, since the regulatory process involves a "complex interplay between those regulating and those regulated," making it "impossible to identify the true "initiator." " 428 U.S. at 610.

"Justice Stevens never explicitly stated whether this second arm of the test for determining when private conduct required by state law is exempt from the antitrust laws need be dealt with if the regulated private party did not initiate the state scheme. Rather, Justice Stevens assumed arguendo that "it would be unacceptable ever to impose statutory liability on a party who had done nothing more than obey a state command." 428 U.S. at 590 . The dissent assumed, on the contrary, that the second tier of the Stevens test became relevant only if the private party did not exercise sufficient freedom of choice to hold him responsible for his actions. Id. at 627.

${ }^{75} \mathrm{Id}$. at 614-15 n.6. For a discussion of a possible privilege defense for acting in conformity with state law, see Posner, The Proper Relationship between State Regulation and the Federal Antitrust Laws, 49 N.Y.U. L. Rev. 693, 728-32 (1974). 
complying with state law, not with liability for petitioning the government. While exercise of the right to petition would be greatly discouraged if liability for damages could result from complying with the governmental action sought, such liability should not attach if a regulatory body makes a policy determination to sanction a particular anticompetitive practice. In the event that a regulatory policy is struck down as repugnant to the antitrust laws, only injunctive relief should be allowed.

\section{The Basis of the Noerr-Pennington Doctrine}

\section{A. Statutory Construction or the First Amendment?}

The principal weakness of the Noerr-Pennington line of cases is the Court's failure to unambiguously articulate the basis for exempting certain lobbying from the reach of the antitrust laws. Noerr suggests that the exemption is based on construction of the Sherman Act.$^{76}$ California Motor Transport indicates that the exemption is predicated upon the first amendment. ${ }^{77}$ The resolution of this ambiguity is crucial, for if all lobbying activities are exempt from the Sherman Act, conduct that is unprotected by the first amendment might nevertheless be immune from the antitrust laws..$^{78}$

The statutory construction arguments advanced by the Court in Noerr have already been considered and dismissed. ${ }^{79}$ Two other possible justifications for holding all lobbying activity, whether or not constitutionally protected, to be beyond the purview of the antitrust laws deserve mention. .

It might be argued that construing the Sherman Act to reach any lobbying activity would conflict with the doctrine of Parker $v$. Brown. ${ }^{80}$ Parker held that the Sherman Act was not designed to prohibit state-imposed monopolies. Noerr's holding that attempts to influence government action are exempt from the antitrust laws might seem a natural extension of Parker. If state action is not illegal under the antitrust laws, the argument goes, attempts to procure such action should not be subject to antitrust liability either. ${ }^{81}$

765 U.S. 127, 136-37 (1960).

77404 U.S. 508, 510-11 (1972).

${ }^{78}$ See, e.g., Cow Palace, Ltd. v. Associated Milk Producers, Inc., 390 F. Supp. 696 (D. Colo. 1975) (holding that illegal lobbying tactics are irrelevant for purposes of the Sherman Act because the Noerr-Pennington doctrine is based on statutory construction of the Sherman Act).

7ee text and notes at notes 18-32 supra.

317 U.S. 341 (1943).

st See Baker, Exchange of Information for Presentation to Government Agencies: The 
This argument is unconvincing for several reasons. First, Parker may be applicable only to suits attacking official action taken by state officials, and not to suits against private individuals. ${ }^{82}$ Second, Cantor makes clear that the Parker exemption does not immunize all anticompetitive private actions taken in compliance with state regulations. Indeed, Cantor suggests that if private parties are responsible for state regulations requiring anticompetitive actions, Parker immunity may be lost. ${ }^{83}$ Third, it is not at all clear that if a governmental act is legal, all attempts to procure that act are automatically legal. ${ }^{84}$ In several cases, for example, courts have upheld antitrust attacks against concerted efforts to influence ratemaking by administrative agencies even though the validity of the established rates was not challenged. ${ }^{85}$ Finally, the analogy to Parker has little force when improper means are used. The advantage of immunizing attempts to influence governmental action when the state action itself is exempt is that government officials will be able to make decisions which restrain trade more effectively if they have adequate sources of information. But this interest is satisfied by exempting attempts to influence the government by means protected by the first amendment.

Another argument for exempting all lobbying activities from the scope of the antitrust laws is that selective use of the Sherman Act would be an "irrational, piecemeal way of regulating lobbying abuses." ${ }^{\prime 86}$ After all, lobbying abuses are not confined to anticompetitive attempts to secure governmental action. This argument, like the Court's concern in Noerr about using the Sherman Act as a code of ethics for political activity, misses the point. The Sherman Act is not invoked in cases of anticompetitive attempts to influence the government as a substitute for direct regulation of lobbying abuses, but as a separate statutory mechanism with different purposes and remedies. The existence or non-existence of direct regulation for lobbying abuses, whether or not anticompetitive in effect, is irrelevant for determining antitrust liability.

The justifications for basing the Noerr-Pennington doctrine on

Interplay of the Container and Noerr Doctrines, 44 ANTTrRUst L.J. 354 (1975).

${ }^{32}$ Compare Cantor v. Detroit Edison Co., 428 U.S. 579, 591 (1976) (opinion of Stevens,

J.), with Bates v. State Bar, 97 S. Ct. 2691, 2698 (1977).

x3 See note 74 supra.

* See Angle v. Chicago, St. P., M. \& O. R.R., 151 U.S. 1 (1894).

ss E.g., Georgia v. Pennsylvania R.R., 324 U.S. 439 (1945).

See Costillo, Antitrust's Newest Quagmire: The Noerr-Pennington Defense, 66 MicH.

L. REv. 333, 348 (1967).

st Note, Application of the Sherman Act to Attempts to Influence Government Action, 81 HARv. L. REv. 847, 850 (1968). 
construction of the antitrust laws have been examined and found wanting. While the Supreme Court has not expressly disavowed the statutory construction bases for the Noerr exemption, the Court's most recent interpretation of the exemption is incompatible with the view that the Sherman Act does not apply to attempts to influence the government. In California Motor Transport ${ }^{87}$ the Court indicated that misrepresentations, bribery, and perjury, at least in the adjudicative context, may give rise to antitrust liability-even though such conduct may well be intended to influence the government. ${ }^{88}$ If resort to the courts in certain circumstances can constitute an antitrust violation, it is difficult to see why resort to the legislative or executive branches should enjoy a blanket statutory exemption. ${ }^{89}$

\section{B. The Right to Petition: Supreme Court Pronouncements}

The first amendment provides that Congress shall make no law abridging the right of the people "to petition the Government for a redress of grievances." Although this right has been described as "among the most precious of the liberties safeguarded by the Bill of Rights,"

1. The Right to Petition the Courts. In a series of cases the Court struck down statutes that prohibited individuals from associating for the purpose of recommending or providing lawyers to persons with legal claims-in particular, victims of racial discrimi-

804 U.S. 508 (1972).

ss Id. at 512-13.

89 Lower court cases which have held that abusive lobbying tactics are protected under Noerr have relied on the statutory construction justification. See, e.g., Cow Palace, Ltd. v. Associated Milk Producers, Inc., 390 F. Supp. 696 (D. Colo. 1975); Schenley Indus., Inc. v. New Jersey Wine \& Spirit Wholesalers Ass'n, 272 F. Supp. 872 (D.N.J. 1967) (both holding that illegal lobbying tactics are irrelevant for purposes of the Sherman Act). But cf. Sacramento Coca-Cola Bottling Co., Inc. v. Teamsters Local 150, 440 F.2d 1096 (9th Cir.), cert. denied, 404 U.S. 826 (1971), where the court noted, "[1]t does not seem to this Court that the doctrines of Noerr and Pennington were intended to protect those who employ illegal means to influence their representatives in government." Id. at 1099.

Some commentators have asserted that cases such as Sacramento "conflict with Noerr, in which the Supreme Court concluded that deliberate deception of public officials, reprehensible as it may be, is of no Sherman Act consequence." Rill \& Frank, Antitrust Consequences of United States Corporate Payments to Foreign Officials: Applicability of Section 2(c) of the Robinson-Patman Act and Sections 1 and 2 of the Sherman Act, 30 VAND. L. REv. 131, 151 (1977). While the broad language in Noerr lends some support to this contention, it must be emphasized that later cases such as California Motor Transport have interpreted Noerr as resting on the first amendment. Under first amendment law, Sacramento is entirely consistent with Noerr.

${ }^{90}$ U.S. Const, amend. I.

" United Mine Workers v. Illinois State Bar Ass'n, 389 U.S. 217, 222 (1967). 
nation and injured workers. ${ }^{92}$

The seminal case on the constitutional right of access to the courts is NAACP $v$. Button, ${ }^{93}$ where the Court struck down a Virginia statute which prohibited NAACP members from associating for the purpose of assisting persons in racial discrimination matters. Button could have been viewed as a precedent of narrow applicability; the whole tenor of the Court's opinion is one of sympathy for the plight of minority citizens for whom "litigation may well be the sole practicable avenue open . . . for redress of grievances." Moreover, the Court was careful to distinguish resort to the courts for political purposes such as the vindication of constitutional rights from the "oppressive, malicious, or avaricious use of the legal process for purely private gain." ${ }^{\text {95 }}$ Later cases interpreting Button, however, expanded the right of access to the courts to situations involving the promotion of economic interests rather than the vindication of constitutional rights. ${ }^{96}$ In Brotherhood of Railroad Trainmen $v$. Virginia State Bar, ${ }^{97}$ for example, the Court specifically rejected the contention that Button could be limited to cases involving political expression. The Button-Railroad Trainmen line of cases was summed up by Mr. Justice Black in United Transportation Union v. State Bar: "The common thread running through our decisions . . . is that collective activity undertaken to obtain meaningful access to the courts is a fundamental right within the protection of the First Amendment." ${ }^{88}$ As this statement suggests, these decisions primarily rested on the first amendment's guarantee of associational freedom but also alluded to the due process right of access to the courts..$^{99}$

Adopting a slightly different view, the Court in California Motor Transport declared that the right of access to the courts is but an aspect of the right to petition. ${ }^{100}$ To hold that groups violate

${ }^{82}$ United Transp. Union v. State Bar, 401 U.S. 576 (1971); United Mine Workers v. Illinois State Bar Ass'n, 389 U.S. 217 (1967); Brotherhood of R. R. Trainmen v. Virginia, 377 U.S. 1 (1964); NAACP v. Button, 371 U.S. 425 (1963).

371 U.S. 425 (1963).

"Id. at 430 .

is Id. at 443 .

" E.g., United Transp. Union v. State Bar, 401 U.S. 576 (1971).

27377 U.S. 1 (1964).

2x 401 U.S. at 585 .

"The source of the constitutional right of access to the courts was long shrouded in uncertainty. See, e.g., Johnson v. Avery, 393 U.S. 483 (1969)); Ex Parte Hull, 312 U.S. 546 (1941). The Court has recently explained that the right of access to the courts is founded on the due process clause. Wolff v. McDonnell, 418 U.S. 539, 579 (1974). See also Bounds v. Smith, 97 S. Ct. 1491 (1977).

${ }^{100} 404$ U.S. 508, 510 (1972) (citing Johnson v. Avery, 393 U.S. 483 (1969); Ex Parte Hull, 
the antitrust laws by resorting to courts and administrative agencies to "advocate their causes and points of view respecting resolution of their business and economic interests vis-a-vis their competitors," said the Court, "would be destructive of rights of association and petition ....."101

The Court's extension of the right to petition to adjudicatory bodies in California Motor Transport was clearly correct. The first amendment right to petition should extend to all branches of government. The right to petition serves two important values. First, it ensures that citizens can present grievances to their government. The nature of the grievance determines which governmental agency is petitioned, but the right of the people to present their claims remains uniformly important. ${ }^{102}$ Second, the right to petition helps ensure that the government is informed. ${ }^{103}$ Courts, like administrative bodies, legislatures and executive agencies, are dependent on interested parties for much information. It might be argued that courts are dependent upon the parties to supply only "adjudicative" facts while policymakers need instruction regarding "legislative" facts from interested individuals. ${ }^{104}$ But the first amendment draws no such distinction, and, in any event, administrative agencies and courts, particularly higher ones like the Supreme Court, exercise considerable policymaking power. ${ }^{105}$

2. The Right to Petition the Legislature and Executive. The Court has never clearly articulated the limits of the right to petition the legislature and executive. ${ }^{106}$ The Court has indicated that the right to petition adjudicatory bodies does not protect abusive practices, ${ }^{107}$ but the scope of the right to petition non-adjudicatory government bodies is shrouded in uncertainty.

312 U.S. 546 (1941)).

${ }^{101} 404$ U.S. at $510-11$ (emphasis added).

${ }^{102}$ See California Motor Transp. Co. v. Trucking Unlimited, 404 U.S. 508, 510 (1972). (1961).

${ }^{103}$ See Eastern R.R. Presidents Conference v. Noerr Motor Freight, Inc., 363 U.S. 127

10s See K. Davis, Administrative Law Text 160 (1972). The nature of the facts determining a legal dispute may control whether a trial-type procedure is required by due process. Compare Bi-Metallic Inv. Co. v. State Bd. of Equalization, 239 U.S. 441 (1915), with Londoner v. Denver, 210 U.S. 373 (1908).

${ }^{105}$ This is not to suggest, however, that conduct protected in the political arena is necessarily protected in the adjudicative. For example, an interested party would be permitted to mail a letter to a legislator expressing his views, but a similar attempt to communicate ex parte with a juror would be impermissible.

${ }^{108}$ In two earlier cases, the Court had construed the Federal Regulation of Lobbying Act, 2 U.S.C. $\$ \S 261-270(1970)$, to avoid tensions with the first amendment right to petition. See United States v. Harriss, 347.U.S. 612 (1954); United States v. Rumely, 345 U.S. 41 (1953).

${ }^{107}$ California Motor Transp. Co. v. Trucking Unlimited, 404 U.S. 508, 512-13 (1972). 
Language in California Motor Transport suggests that unethical conduct enjoys more constitutional protection in the political arena. After taking note of a statement in Noerr that the unethical nature of the defendants' activities was irrelevant to determining Sherman Act liability, ${ }^{108}$ the Court distinguished the effect of unethical conduct in the adjudicative context:

[U]nethical conduct in the setting of the adjudicatory process often results in sanctions. Perjury of witnesses is one example. Use of a patent obtained by fraud to exclude a competitor from the market may involve a violation of the antitrust laws . . . . [B]ribery of a public purchasing agent may constitute a violation ....

There are other forms of illegal and reprehensible practice which may corrupt administrative or judicial processes and which may result in antitrust violation. Misrepresentations, condoned in the political arena, are not immunized when used in the adjudicatory process . . . ${ }^{109}$

This passage is troublesome in several respects. First, the implication of Justice Douglas's opinion that unethical practices are only subject to sanction in an adjudicative setting is simply incorrect. Perjury and bribery are prohibited in both the legislative and adjudicative contexts. ${ }^{110}$ Misrepresentations, as well as other reprehensible tactics, have also been subjected to regulation and prohibition in the political arena. ${ }^{11}$ Thus, even if the Court was correct in gauging the scope of the right to petition by the existence of sanctions for the general type of activity involved, the Court's distinction between the level of protection afforded conduct in the adjudicatory context and that afforded lobbying is unsupported. A second

${ }^{10 x} 365$ U.S. at $140-42$.

10s Id. at 512-13. The concurring opinion adopted this same dichotomy between unethical practices in the political and adjudicatory arenas: "The difference in type of governmental body might make a difference in the applicability of the antitrust laws if the petitioners had made misrepresentations of fact or law to these tribunals, or had engaged in perjury, or fraud, or bribery." Id. at 517 .

t10 See, e.g., 18 U.S.C. $\$ 201$ (1970) (imposing criminal penalities for bribery or attempted bribery of federal officials); 18 U.S.C. $\$ 1001$ (1970) (imposing criminal penalties for knowingly and willfully concealing or misrepresenting material facts before any department or agency of the United States); 18 U.S.C. $\$ 1621$ (1970) (imposing criminal penalties for perjury before a competent tribunal of the United States).

"See Developments in the Law-Elections, 88 HaRv. L. REv. 1111, 1272-98 (1975). In a recent case which was summarily affirmed by the Supreme Court, a three-judge district court stated that a statute regulating deceptive campaign speech by political candidates would be constitutional if it incorporated the New York Times actual malice standard. Vanasco v. Schwartz, 401 F. Supp. 87 (S.D.N.Y. 1975), aff'd, 423 U.S. 1041 (1976). 
problem is the Court's failure to explain why the independent legality vel non of a course of conduct should determine whether it is protected by the right to petition. That behavior is prohibited is perhaps evidence that it is unprotected by the first amendment. But the converse is not true-activity is not protected by the first amendment because it has not been specifically prohibited or penalized. Thus, the Court in California Motor Transport failed to adequately explain why the unethical nature of petitioning activity should be relevant to the scope of first amendment protectionand specifically to the scope of an antitrust exemption-in the adjudicatory context, but, as Noerr suggested, irrelevant to the protection of speech in the political arena.

\section{A General Framework}

The California Motor Transport opinion established that the Noerr doctrine is based on the first amendment rights of petition and association. ${ }^{112}$ Furthermore, it has been argued that there is no rationale for fashioning an exemption from the antitrust laws for lobbying activity broader than that required by the first amendment. ${ }^{113}$ But a principled basis for ascertaining the scope of the first amendment right to petition the government to take anticompetitive action has never been articulated. Almost all Supreme Court cases referring to the right to petition do not analyze this right separately from the cognate first amendment rights of assembly, association, and speech. ${ }^{114}$ It would be sensible to employ first amendment principles developed in free speech cases to guide application of the Noerr-Pennington doctrine. This appropriation of principles is justified because the values promoted by the first amendment free speech guaranty and those advanced by the Noerr doctrine are very similar.

A primary purpose of freedom of speech is to ensure that the electorate has the information necessary to properly discharge its self-governing responsibilities. ${ }^{115}$ The right to petition the government is a necessary adjunct to freedom of speech under the first amendment qua guarantor of informed self-government because most important public questions are resolved by representatives in government, not plebiscites. The Noerr doctrine preserves the rights of businessmen to press the government for resolution of certain

112404 U.S. at 510.

${ }^{113}$ See text and notes at notes 18-31, 79-89 supra.

is See note 13 supra.

115 See generally A. Meiklejohn, Political Freedom (1960); Brennan, The Supreme Court and the Meiklejohn Interpretation of the First Amendment, 79 HaRv. L. Rev. 1 (1965); Kalven, The New York Times Case: A Note on "The Central Meaning of the First Amendment," 1964 Sup. CT. REv. 191. 
legal, economic, and social problems. This advocacy properly includes presentation of facts and opinions. It does not include deliberately false statements of fact because presentation of falsehoods to government officials does not promote well-considered and wellfounded decisions.

Of course, the right to petition does more than ensure that government officials are apprised of the opinions held and the facts known by the citizenry. It also promotes confidence that the government is accessible and answerable to the people. That the petitioning activity is of no value to the government does not mean that the petitioning is of no legitimate value to the petitioner and his cocitizens. Moreover, when recognized standards dictate a particular governmental decision, as is often the case in the judicial arena, the petitioner may have an important interest in - a right to-the indicated decision.

On the other hand, a petitioner's psychic interest in prosecuting a patently frivolous claim or lying to a government agency is insufficiently important to warrant exempting such conduct from the antitrust laws. Indeed, construing the right to petition to protect deliberate misrepresentations and baseless claims not presented in good faith would devalue the first amendment right to petition. The people, acting through their representatives, have decided that, as a general rule, competition is to be promoted through the antitrust laws. Protecting deliberate misrepresentations to government officials which result in harm to competition, for example, would subvert the government's decision to promote competition, a decision that is the consequence of genuine exercise of the right to petition.

The Supreme Court has declared that there is no constitutional value in false statements of fact. ${ }^{116}$ Similarly, the Court has ruled that prosecution of a baseless claim in an adjudicative setting is not worthy of constitutional protection for its own sake. ${ }^{117}$ These positions are easily reconciliable with the language of the first amendment guaranteeing the right to petition because in these situations there are no "grievances" to redress. It is necessary, however, to protect some false statements and baseless claims in order to avoid inhibiting valuable petitioning. ${ }^{118}$ As in the free speech context, spe-

"16 Gertz v. Robert Welch, Inc., 418 U.S. 323, 339-40 (1974); Vanasco v. Schwartz, 401 F. Supp. 87, 191 (S.D.N.Y. 1975), aff'd, 423 U.S. 1041 (1976). This was not always the Court's view. Garrison v. Louisiana, 379 U.S. 64, 85 (1964); New York Times Co. v. Sullivan, 376 U.S. 254, 279 n.19 (1964); Cantwell v. Connecticut, 310 U.S. 296, 310 (1940).

:17 Walker Process Equip., Inc. v. Food Mach. \& Chem. Corp. 382 U.S. 172 (1965).

"1s The approach of the lower courts has been to base the decision of whether deliberate misrepresentations are protected by the Noerr-Pennington doctrine on the type of governmen- 
cial protective rules are required.

In libel law it is well-established that a public figure may constitutionally recover only by clear and convincing proof that the defendant's false and defamatory statement was made with actual malice - that is, with knowledge of its falsity or with reckless disregard for its truth. ${ }^{119}$ This standard of care could perhaps be used to define the limits of speech protection in the Noerr context. ${ }^{120}$ It might be thought that the knowing or reckless falsehood standard is overprotective of first amendment values in the Noerr context. In a series of cases holding that commercial speech is protected by the first amendment, the Court has reserved the question whether false or deceptive commercial speech may be more rigorously regulated than false speech outside the commercial context. The doctrinal bases for this reservation are that commercial speech is more easily verified than political speech and that commercial speech is hardier than political speech because of the financial incentives to advertise. ${ }^{121}$ The latter rationale might seem to be applicable to attempts to influence the government to take anticompetitive action. But it is doubtful that such activity is as durable as advertising - the paradigmatic form of commercial speech. Often the risk of treble damage liability will outweigh the expectation of returns from petition-

tal body involved. Compare Woods Exploration \& Prod. Co. v. Aluminum Co. of America, 438 F.2d 1286 (5th Cir. 1971), cert. denied, 404 U.S. 1047 (1972) (deliberate filing of false forecasts with adjudicatory body unprotected by Noerr), with Metro Cable Co. v. City of Rockford, 516 F.2d 220 (7th Cir. 1975) (deliberate misrepresentations made to City Council which allegedly resulted in the denial of a cable television franchise protected under Noer because the Council was a legislative rather than an adjudicatory body), and Franchise Realty Interstate Corp. v. San Francisco Local Joint Executive Bd., 542 F.2d 1076 (9th Cir. 1976), cert. denied, $97 \mathrm{~S}$. Ct. 1571 (1977) (holding that the dissemination of maliciously false material through the media falls within the scope of the Noerr-Pennington doctrine). Once it is recognized that the Noerr doctrine rests on the first amendment, deliberately false statements should not be protected. See text and note at note 116 supra; text and notes at notes 124-129 infra.

11 New York Times Co. v. Sullivan, 376 U.S. 254 (1964).

${ }_{120}$ Only one case has considered the relationship between the New York Times actual malice standard and Noerr. In Sierra Club v. Butz, 349 F. Supp. 934 (N.D. Cal. 1972), the court rejected the New York Times standard in a civil suit seeking to recover damages caused by the exercise of the right of petition in favor of the broader protection of Noerr. Cf. United States v. Harriss, 347 U.S. 612, 635 (1954) (Jackson, J., dissenting) (stating that the first amendment protects the right to petition the government even if the effect of the exercise of this right is "deceiving and corrupting").

${ }^{221}$ Bates v. State Bar, 97 S. Ct. 2691, 2708-09 (1977); Carey v. Population Servs. Int'l, 97 S. Ct. 2010 (1977); Linmark Assocs., Inc v. Town of Willingboro, 97 S. Ct. 1614, 1618 (1977); Virginia State Bd. of Pharmacy v. Virginia Citizens Consumers Council, Inc., 425 U.S. $748,771-72$ \& n.24 (1976). For the same reasons, the overbreadth doctrine, which is an exception to conventional standing principles based on the fragility of speech, does not apply in commercial speech cases. Bates v. State Bar, 97 S. Ct. 2691, 2707-08 (1977). 
ing activity. The objectivity rationale is more clearly inapplicable. Because such petitioning may involve many types of statements made in a variety of situations, no generalizations about the verifiability of such speech can be safely made.

On the other hand, it may be argued that the knowing or reckless falsehood standard is insufficiently protective of first amendment values in the Noerr context. To the extent that the standard represents an accommodation between society's interest in free debate and its interest in protecting the reputations of its citizens, it could be argued that false statements should be unconditionally privileged since the reputation interest is generally absent in the lobbying area. ${ }^{122}$ The dangers of false speech, moreover, are noticeably greater in the typical libel situation, where the harm to the individual occurs at the time of the statement and where there is no opportunity for effective counter-speech. In the lobbying context, by contrast, the harm resulting from false speech does not occur until it has been acted upon by a government official. Typically competitors have ample opportunity to rebut any false claims and present their own views. It may be, therefore, that unfettered interchange in the "marketplace of ideas"123 provides an adequate safeguard against the harmful effects of the false statements in the course of lobbying.

Nevertheless, recent developments in the regulation of speech in election campaigns suggest that the "knowing or reckless" falsehood standard is sufficiently protective of first amendment interests in the area of lobbying activity. Many states now have statutes regulating deceptive campaign speech. ${ }^{24}$ Most of these statutes cover any false statement concerning any candidate. ${ }^{125}$ Typically, sanctions include criminal penalties of fine or imprisonment. ${ }^{128}$ In a recent case, which was summarily affirmed by the Supreme Court, ${ }^{127}$ a three-judge court stated that one such statute regulating deceptive campaign speech by political candidates would be constitutional if the statute incorporated the knowing or reckless falsehood standard. ${ }^{128}$ Since election campaigns provide the classic example of "no holds barred" interchange where the law has traditionally assumed that the "marketplace of ideas" would adequately

\footnotetext{
12 See Gertz v. Robert Welch, Inc., 418 U.S. 323, 341 (1973).

12 Whitney v. California, 274 U.S. 357, 375-77 (1927) (Brandeis, J., concurring).

124 See Elections, supra note 111, at 1272-74.

125 See Id. at 1273.

${ }^{26}$ See Id. at 1274.

17 Vanasco v. Schwartz, 401 F. Supp. 87 (S.D.N.Y. 1975), aff'd, 423 U.S. at 1041 (1976).

128401 F. Supp. at 92.
} 
protect against false speech, it is unlikely that false speech would enjoy greater first amendment protection under the guise of the right to petition. ${ }^{129}$

\section{THE "ShAM" EXCEPTION}

The Court has consistently held that the exemption from the antitrust laws for attempts to influence the government is inapplicable when such conduct is a "sham." The determination of whether petitioning activity is a sham, however, has been plagued by considerable confusion.

\section{A. Sham Attempts to Influence Legislative and Executive Bodies}

Although the Court in Noerr held that attempts to influence the passage or enforcement of laws were exempt from the Sherman Act, it added in dictum:"There may be situations in which a publicity campaign, ostensibly directed toward influencing governmental action, is a mere sham to cover what is actually nothing more than an attempt to interfere directly with the business relationships of a competitor and the application of the Sherman Act would be justified." ${ }^{130}$ Noerr did not present an occasion for applying the sham exception because "[n]o one denies that the railroads were making a genuine effort to influence legislation and law enforcement practices."131 The injury suffered by the plaintiff truckers was just an "incidental effect of the railroads' campaign to influence governmental action." 132

The parameters of the sham exception announced in Noerr are unclear. One difficulty arises from the Court's equation of attempts "to interfere directly with the business relationships of a competitor" with activity not genuinely intended to influence the government. This equation is simply inaccurate. If, for example, a group of competitors, in order to facilitate a price-fixing arrangement, exchange information under the cover of a sham lobbying campaign, this would not directly interfere with the business relationships of a competitor yet it would constitute a spurious attempt to influence

${ }^{129}$ It could be argued that application of the antitrust laws to speech is a matter quite different from the application of election laws because the Sherman Act is so broadly worded. There is no constitutional infirmity, however, in applying a generally worded statute to unprotected speech. See, e.g., Schenk v. United States, 249 U.S. 47 (1919).

130365 U.S. at 144.

131 Id. at 144.

${ }^{32}$ Id. at 143. 
the government. ${ }^{133}$ It is likely that the Court did not intend to limit the sham exception to attempts to directly interfere with the business relationships of a competitor. The troublesome language was probably meant to be illustrative, not definitional. The Court was primarily concerned in Noerr that the Sherman Act not be used to regulate or penalize attempts to influence the passage or enforcement of laws. Construing the sham exception as enunciated in Noerr to include all activity not genuinely designed to influence the government is more consonant with the Court's central ruling.

In hindsight, the sham exception announced in Noerr suffers a more fundamental defect. The Noerr-Pennington doctrine, it has been argued, should exempt only activity protected by the first amendment from antitrust liability. The sham exception as defined in Noerr brings petitioning activity which is not genuinely designed to influence the government within the purview of the antitrust laws. So defined, the sham exception is both over-inclusive and under-inclusive. On the one hand, petitioning which is not genuinely intended to influence the government may be of constitutional value. For example, suppose that a businessman accurately presents important facts to a government agency, intending that the disclosure harm a competitor's business by provoking an adverse public reaction, but not intending that the government act on the information he provides. Both the government and the public should be entitled to the information regardless of the businessman's intentions. This is just an illustration of the principle that valuable speech is not deprived of first amendment protection by

13 This example raises the problem of the relationship between the Noerr-Pennington doctrine and the rule of United States v. Container Corp. of America, 393 U.S. 333 (1969), which prohibits exchanges of information among competitors in certain circumstances. See generally L. Sullivan, ANTTTRust 265-74 (1976).

Competitors will often collect and disseminate information in preparation for petitioning the government. Cumulative price and sales data, for example, may be necessary for lobbying before legislatures, executives, or presentation to government agencies. If the dissemination of such information would not be illegal under Container Corp., no problem arises. A conflict between Noerr and Container does arise, however, if an exchange of information would be illegal under Container, but, at the same time, is necessary for a legitimate presentation to the government. Since no court has ever had to face this conflict, its resolution is uncertain. Cf. I.C.L. Theatres, Inc. v. Columbia Pictures Indus., Inc., 1976 Trade Cases $\mid$ 60,964 (N.D. Tex. 1976) (possible conflict between Noerr and Container Corp. suggested). An exchange of information should be protected under Noerr if it is necessary to, and made for the purpose of, genuinely attempting to influence government action. However, if competitors agree to adhere to a price schedule after an exchange of information and then attempt to immunize themselves by simply forwarding this information to the government, the price-fixing agreement would not be protected by the Noerr doctrine. Cf. Commerce Tankers v. Nat'l Maritime U. of America, 553 F.2d 793, 800 (2d Cir. 1977) (an illegal group boycott cannot be immunized by the bringing of a lawsuit to enforce it). 
the speaker's improper motive. ${ }^{134}$ On the other hand, all speech and activity which is intended to influence the government does not warrant first amendment protection. Bribery ${ }^{135}$ and perjury ${ }^{136}$ are obvious examples.

Thus, the sham exception announced in Noerr is inconsistent with the first amendment basis of the Noerr-Pennington exemption. The sham exception should be reinterpreted to encompass all petitioning activity which is unprotected by the first amendment.

\section{B. Sham Attempts to Influence Adjudicative Bodies}

The complaint in California Motor Transport alleged that the defendants conspired to monopolize trade in the transportation of goods by opposing, with or without probable cause, the plaintiffs' applications to obtain motor carrier operating rights in California. The alleged purposes of the conspiracy were to eliminate existing and potential competition and to deny plaintiffs "free and unlimited" access to the tribunals which regulated the highway common carrier business in California. The defendants moved to dismiss the complaint for failure to state a cause of action, relying on a statement in Pennington that "Noerr shields from the Sherman Act a concerted effort to influence public officials regardless of intent or purpose."137 The Court held that the complaint stated a cause of action within the sham exception to Noerr because of the allegations that the conspirators were not genuinely intent upon influencing public officials but upon harassing the plaintiffs. ${ }^{138}$

It will be recalled that the Court in California Motor Transport emphasized that unethical conduct, often condoned in the political context, might not be condoned in the adjudicatory context. Some courts ${ }^{139}$ and commentators, ${ }^{140}$ relying on this language, have argued that unethical or abusive conduct in adjudicative fora constitutes a

13 The Court has held that the truth is a constitutionally required, absolute defense to a libel suit. Gertz v. Robert Welch, Inc., 418 U.S. 323, 340-41 (1974).

133 United States v. Marchetti, 466 F.2d 1309, 1314 (4th Cir. 1972).

134 California Motor Transp. Co. v. Trucking Unlimited, 404 U.S. 508, 512-13 (1972).

${ }^{137} 381$ U.S. at 670, quoted in California Motor Transp. Co. v. Trucking Unlimited, 404 U.S. 508, 511 (1972).

เ39 404 U.S. at 515-16.

${ }^{139}$ E.g., Israel v. Baxter Laboratories, Ltd., 466 F.2d 272 (D.C. Cir. 1972); Semke v. Enrid Auto. Dealers Ass'n, 456 F.2d 1361 (10th Cir. 1972); United States Dental Inst. v. American Ass'n of Orthodontists, 396 F. Supp. 565 (N.D. Ill. 1975).

140 See, e.g., Note, Limiting the Antitrust Immunity for Concerted Attempts to Influence Courts and Adjudicatory Agencies: Analogies to Malicious Prosecution and Abuse of Process, 86 HaRv. L. REv. 715 (1973). 
sham. In Semke v. Enid Automobile Dealers Association, ${ }^{141}$ for example, the Tenth Circuit defined the sham exception in the adjudicatory context as "misuse or corruption of the legal process." 142 Similarly, the District of Columbia Circuit, in Israel v. Baxter Laboratories, Inc. ${ }^{143}$ stated that activities that "impair the fair and impartial functioning of an administrative agency"144 are a sham. ${ }^{145}$ Under this interpretation of California Motor Transport, there are two sham exceptions. Attempts to influence the legislature or executive by unethical or abusive conduct will not be labeled a sham unless there is no genuine intent to influence governmental action. In contrast, abusive or unethical conduct in an adjudicative setting is a sham regardless of whether there is a genuine design to influence the government. ${ }^{148}$ It is unlikely, however, that the Court in California Motor Transport intended to erect such an anomalous standard. ${ }^{147}$ California Motor Transport squarely placed the Noerr-Pennington doctrine on a first amendment footing. The discussion of abusive tactics was probably intended to help define the limits of the first amendment right to petition adjudicative bodies, not to create a separate definition for the sham exception. ${ }^{148}$

The suggested interpretation of California Motor Transport is supported by the Court's decision in Otter Tail Co. v. United States. ${ }^{149}$ In Otter Tail, the government brought a civil antitrust

is 456 F.2d 1361 (10th Cir. 1972).

142 Id. at 1366.

143 466 F.2d 272 (D.C. Cir. 1972).

id Id. at 278.

is See also REA Express, Inc. v. California Motor Transp. Co., 1975 Trade Cases I 60,386 (N.D. Cal. 1975) (courts must apply a stricter standard in determining whether lobbying activities constitute a sham in the adjudicatory context).

tw Aloha Airlines, Inc. v. Hawaiian Airlines, Inc., 349 F. Supp. 1064 (D. Haw. 1972), aff'd, 489 F.2d 203 (9th Cir.), cert. denied, 427 U.S. 913 (1974), suggests still another interpretation of the sham exception. In Aloha, the court held that a complaint that alleged that defendant opposed an application before the $C A B$ with "the predatory intent and purpose of eliminating plaintiff as a viable competitor" stated a cause of action under the sham exception. This interpretation of the sham exception, which equates anticompetitive intent with illegality, is directly contrary to both Noerr and California Motor Transport.

157 As the court in Adolph Coors Co. v. A \& S Wholesalers, Inc., 1975 Trade Cases I 60,187, at 65,634 (D. Colo.), aff'd, 1977 Trade Cases \ 61,562 (10th Cir.), correctly stated:

It is crucial to an understanding of the "sham" exception in the adjudicatory context to note that the complaint in California Motor Transport alleged that the defendants invoked the adjudicatory processes not for decisional purposes but solely to deter plaintiffs from use of the machinery, and thus to deny them "meaningful access" to the decisionmaking processes.

14k This interpretation is buttressed by the majority's approving reference to the concurring opinion which emphasized that defendant's activities fell within the sham exception as defined by Noerr. 404 U.S. at 512.

143 331 F. Supp. 54 (D. Minn. 1971), aff'd in part, vacated in part, 410 U.S. 366 (1973). 
suit, alleging that defendants both instituted and sponsored litigation opposing a proposed municipal power system. While none of these lawsuits were successful, they nevertheless helped frustrate the sale of revenue bonds to finance the power system. The district court, writing before California Motor Transport, held that the Noerr-Pennington doctrine was inapplicable to the institution of judicial proceedings. The Supreme Court vacated the district court's judgment for reconsideration in light of California Motor Transport, but stated that California Motor Transport established that the sham exception applies "where the purpose to suppress competition is evidenced by repetitive lawsuits carrying the hallmark of insubstantial claims . . . " ${ }^{50}$ By focusing on the repetitive and insubstantial nature of the claims, the Court suggested that the conduct alleged in California Motor Transport constituted a sham because there was no genuine attempt to influence governmental action.

Although California Motor Transport and Otter Tail are most fairly read as equating the sham exception with the absence of a genuine intent to influence the government, language in both opinions lends support to a view of the sham exception that accords with the first amendment justification for the Noerr-Pennington doctrine. Both opinions emphasized that repeated prosecutions of baseless or insubstantial lawsuits are paradigmatically within the sham exception. The repetitious filing of baseless lawsuits does indeed indicate that any professed intent to influence the courts is spurious. There is also, however, no substantial first amendment interest in ensuring that baseless claims are presented to adjudicative bodies. The repetition constituent of the formula can be read as guaranteeing that the plaintiff knows his claim to be unmeritorious. Therefore, a plaintiff who repeatedly institutes baseless suits to harm a competitor may be subjected to antitrust liability without discouraging exercise of first amendment freedoms.

Some lower courts have split on the question whether the filing of a single lawsuit, as opposed to a pattern of baseless litigation, can constitute a sham. ${ }^{151}$ Last Term in Vendo Co. v. Lektro-Vend

${ }^{150} 410$ U.S. at 380 . On remand, the District Court held, without discussion, that the allegations of the complaint stated a cause of action under the sham exception. $360 \mathrm{~F}$. Supp. 451 (D. Minn. 1973). The Supreme Court summarily affirmed. 417 U.S. 901 (1974).

ist Compare Central Bank of Clayton v. Clayton Bank, 424 F. Supp. 163 (E.D. Mo. 1976), aff'd, 553 F.2d 102 (1977); Rush-Hampton Indus., Inc. v. Home Ventilating Inst., 419 F. Supp. 19 (M.D. Fla. 1976); and Bethlehem Plaza v. Campbell, 403 F. Supp. 966 (E.D. Pa. 1975) (all suggesting that a pattern of baseless litigation is necessary), with Associated Radio Serv. Co. v. Page Airways, Inc., 414 F. Supp. 1088 (N.D. Tex. 1976) (holding that the filing of one lawsuit can constitute a sham). 
Corp. ${ }^{152}$ this issue surfaced in the Supreme Court. The central issue in Lektro-Vend was whether section 16 of the Clayton Act, ${ }^{153}$ which authorizes injunctions against violations of the antitrust laws at the instance of private parties, expressly authorizes injunctions against state court proceedings within the meaning of the anti-injunction statute. ${ }^{154}$ Mr. Justice Rehnquist, speaking for three members of the Court, ruled that section 16 does not. ${ }^{155} \mathrm{Mr}$. Justice Blackmun, joined by the Chief Justice, concurred in the result reached by Justice Rehnquist, holding that no injunction may issue against a state court proceeding unless it is "part of a "pattern of baseless repetitive claims." "156 Justice Stevens, joined by three other justices, dissented, arguing that section 16 expressly authorizes injunctions against state court actions which violate the antitrust laws. ${ }^{157}$

Upon first examination, it appears that the basis of the dispute between Justice Blackmun and Justice Stevens is a disagreement over whether the bringing of a single state lawsuit can violate the antitrust laws. Justice Blackmun relied on the cases explicating the sham exception to the Noerr-Pennington doctrine, in which the multiplicity of suits was indeed emphasized. Justice Stevens relied on a wider range of cases in which improper use of judicial process was held to be an antitrust violation. For example, Justice Stevens discussed Walker Process Equipment, Inc. v. Food Machinery \& Chemical Corp. ${ }^{158}$ which held that enforcement of a fraudulently procured patent could violate section 2 of the Sherman Act.

Justice Stevens's interpretation of the relevant precedents is irrefutable. Walker Process does indeed establish that bringing a single lawsuit can violate the antitrust laws. Walker Process was not, however, a case interpreting the sham exception. Walker Process involved a genuine attempt to influence the government by improper means. Walker Process is authority for revising the sham exception to include all petitioning unprotected by the first amendment, but it is not inconsistent with an interpretation of the traditional sham exception requiring a pattern of baseless litigation.

Closer examination of Justice Blackmun's opinion in LektroVend reveals that he has not necessarily committed himself to the

15297 S. Ct. 2881 (1977).

13315 U.S.C. $\S 26$ (1970).

15s 28 U.S.C. $\S 2283$ (1970). See generally Redish, The Anti-Injunction Statute Reconsidered, 44 U. CHI. L. Rev. 717 (1977).

$15597 \mathrm{~S}$. Ct. at $2887-89$.

158 Id. at 2893 (Blackmun, J., concurring in the result).

157 Id. at $2897-98$.

15n 382 U.S. 172 (1965). 
view that a multiplicity of suits is required to prove either a sham or an antitrust violation. In a footnote Blackmun stated: "Since I believe that federal courts should be hesitant indeed to enjoin ongoing state proceedings, I am of the opinion that a pattern of baseless, repetitive claims or some equivalent showing of abuse must exist before an injunction would be proper." 159 This passage suggests that Blackmun's view was predicated not upon antitrust doctrine, but upon his view of the anti-injunction statute.

Thus, lower courts will find little instruction in Lektro-Vend when deciding whether a single lawsuit can constitute a sham. The touchstone of the traditional sham exception-the absence of a genuine intent to influence the government-suggests that although repeated lawsuits are highly probative, they are not necessary to constitute a sham. Similarly, a litigant need not repeatedly institute baseless litigation in order for his activities to fall within the revised sham exception proposed in this article. Objective proof that the litigant knew he was instituting a single baseless lawsuit would suffice. ${ }^{160}$

15997 S. Ct. at 2893 n.*.

160 The Ninth Circuit has recently reinterpreted the sham exception. Franchise Realty Interstate Corp. v. San Francisco Local Joint Executive Bd., 542 F.2d 1076 (9th Cir. 1976), cert. denied, 97 S. Ct. 1571 (1977). Plaintiffs, subsidiaries of McDonald's, alleged that defendants, two associations of restaurant and hotel employees and a labor union, had conspired to "oppose, repeatedly, baselessly, and in bad faith, the granting of building permits," $i d$. at 1078, by the San Francisco Board of Permit Appeals. The complaint further alleged that defendant's actions denied plaintiffs "free and unlimited access" to municipal authorities. The Ninth Circuit, however, affirmed dismissal of plaintiff's complaint. In the first place, the court stated that the sham exception "does not extend to direct lobbying efforts such as those alleged here." Id. at 1080 . Second, even if the sham exception does apply to direct lobbying efforts, by definition it does not reach situations in which the defendant is genuinely attempting to influence government action. Because the defendants had successfully opposed plaintiffs' applications for building permits, the court found it "particularly hard" to characterize defendants' conduct as a sham. Id. at 1079. Third, the plaintiffs had only alleged in a conclusory manner that they had been denied access to municipal agencies. To permit plaintiffs to proceed to discovery on the basis of notice pleading would impermissibly inhibit exercise of the first amendment right to petition the government. Id. at 1082.

The first ground of the Ninth Circuit's decision is unsupported by precedent or principle. Otter Tail and California Motor Transport held that abuse of the right of access to adjudicatory tribunals can constitute a sham in the absence of any abusive conduct external to the adjudicatory process, see text and notes at notes 137-150 supra, and constitutionally valueless activity that adversely affects competition should not be immunized from antitrust liability. See text and notes at notes 150-152 supra. The third rationale advanced by the Ninth Circuit is attractive, but not recognized in other constitutional cases and contrary to the rule that dismissals should rarely be granted prior to discovery in antitrust cases. $542 \mathrm{~F} .2 \mathrm{~d}$ at 1090 (Browning, J., dissenting).

The central question presented in Franchise is whether successful petitioning can ever be a sham. See also Taylor Drug Stores, Inc. v. Associated Dry Goods Corp., 561 F.2d 211 (6th Cir. 1977) (holding that a single successful lawsuit cannot constitute a sham). On the 


\section{Special Problems of Application}

The Noerr-Pennington exemption can plausibly be asserted in a variety of factual and legal situations. Unresolved questions remain concerning the exemption's application in most of these situations.

\section{A. Patent Infringement Cases}

In California Motor Transport the Court held that access to the courts is protected by the first amendment's guarantee of the right to petition. ${ }^{181}$ On this point the Court reversed the Ninth Circuit, which had ruled that the Noerr exemption does not immunize attempts to influence adjudicative bodies. The Ninth Circuit's opinion relied on a line of patent infringement cases in which use of the courts to achieve anticompetitive ends was held an antitrust violation. ${ }^{162}$ The impact of California Motor Transport on these patent

one hand, that a legal claim is vindicated by the government is objective and strong evidence that the petitioner did not knowingly prosecute a baseless claim. But if the Noerr-Pennington exemption rests on the first amendment, the success of the petitioning activity should not be dispositive: lobbying activity characterized by abusive tactics should not enjoy antitrust immunity even if successful.

A related problem is presented when a party injured by governmental action that was taken as a result of petitioning activity unprotected by the Noerr-Pennington exemption seeks to recover damages from the petitioners. Compare Okefenokee Rural Elec. Membership Corp. v. Florida Power \& Light Co., 214 F.2d 413 (5th Cir. 1954) (damages are not recoverable when there is an intervening governmental act), with Woods Exploration \& Producing Co. v. Aluminum Co. of America, 438 F.2d 1286 (5th Cir. 1971), cert. denied. 404 U.S. 1047 (1972) (damages recoverable despite intervening governmental act).

Strong policy considerations support finding antitrust liability in at least some cases. In the case where a monopolist extends his monopoly position by bribing members of a city council, penalties for bribery or injunctive relief will not provide an adequate deterrent, since the monopolist may have reaped windfall profits as a result of his lobbying efforts. Treble damages are the only effective sanction. It should be emphasized, however, that situations where the causal connection between the defendant's conduct and the governmental action is strong enough to impose liability will probably be relatively rare. It may not always be clear whether the tactics of private parties were material, since precisely the same governmental action might have resulted in the absence of lobbying tactics unprotected by the NoerrPennington doctrine. Cf. Angle v. Chicago, St. P., M. \& O. Ry., 151 U.S. 1 (1894) (the Court upheld the award of damages for malicious interference with contractual relations that was caused by successful petitioning). In United Mine Workers v. Pennington, 381 U.S. 657, 67172 (1965), however, the Court implied that no damages could be awarded where there had been an intervening governmental act.

III 404 U.S. 508, 510-11 (1972).

112 Walker Process Equip., Inc. v. Food Mach. \& Chem. Corp., 382 U.S. 172 (1965); United States v. Singer Mfg. Co., 374 U.S. 174 (1963); Kobe, Inc. v. Dempsey Pump Co., 198 F.2d 416 (10th Cir. 1952); Lynch v. Magnovox Co., 94 F.2d 883 (9th Cir. 1938), cited in Trucking Unlimited v. California Motor Transp. Co., 432 F.2d 755 (9th Cir. 1970), rev'd in part and aff'd in part, 404 U.S. 508 (1972).

The Ninth Circuit also relied on a report advocating the position that a patent infringe- 
infringement cases must be assessed.

1. United States v. Singer Manufacturing Co. In United States $v$. Singer Manufacturing Co., ${ }^{163}$ the government brought an antitrust action against Singer, the sole manufacturer of household zigzag sewing machines, for conspiring with two foreign competitors to exclude Japanese competition. The conspirators allegedly withdrew opposition to each others' patent applications in order to secure broad patents, invalidity considerations notwithstanding, and cross-licensed the broad patents obtained so that Singer could enforce the patents in the United States to the exclusion of Japanese competitors. Underlying these transactions the trial court discerned "a common purpose to suppress the Japanese machine competition"164 through infringement suits. The Supreme Court held that Singer therefore violated section 1 , even though the infringement claims were not unfounded.

Singer was decided after Noerr but before California Motor Transport. Singer and Noerr are reconcilable only if the antitrust immunity for attempts to influence the government does not extend to attempts to influence the courts. But the right of competitors to band together and utilize the courts to exclude competitors, the practice condemned in Singer, was held constitutionally protected in California Motor Transport. The only difference between the two cases is that Singer involved additional activities, such as the collusive termination of a Patent Office interference proceeding, a practice which a concurring opinion found to be an independent antitrust violation. ${ }^{165}$ Pennington, however, was also a case in which the defendants had engaged in activities other than those protected by Noerr, yet the Court there held that attempts to influence the government are protected even if part of a larger anticompetitive scheme. ${ }^{166}$ The broad rule of Singer, therefore, can no longer be considered good law.

2. Kobe, Inc. v. Dempsey Pump Co. In a series of cases, some decided before and some after California Motor Transport, several

ment suit can constitute an antitrust violation:

Where it has been shown that an infringement suit has, in fact, been brought as an integral part of an agreement or plan to violate the antitrust laws and that the defendant sustained resulting damages, treble damages for antitrust violation should be recoverable, whether or not there was a colorable claim of infringement.

Report of the Attorney General's National Committee to Study the Antitrust Laws 24748 (1955).

163374 U.S. 174 (1963).

161 Id. at 194 (footnote omitted).

16s Id. at 197 (White, J., concurring).

${ }^{165}$ See text at note 35 supra. 
courts have held that the bringing of a patent infringement action can be an antitrust violation if part of an attempt to monopolize. ${ }^{167}$ In the leading case of Kobe, Inc. v. Dempsey Pump Co., ${ }^{168}$ for example, the alleged infringers of a patent counterclaimed for treble damages, charging that the patent holder had achieved a monopoly position by acquiring and pooling patents and that the infringement action was brought to enforce this monopolistic scheme. The holders of the patents contended that they had a right to use the courts to protect their interests. The Tenth Circuit rejected this argument, finding that the real purpose of the infringement action was to further the existing monopoly and eliminate competitors:

We fully recognize that free and unrestricted access to the courts should not be denied or imperiled in any manner. At the same time we must not permit the courts to be a vehicle for maintaining and carrying out an unlawful monopoly which has for its purpose the elimination of competition. ${ }^{189}$

Kobe holds that the maintenance of an otherwise valid infringement action is violative of the antitrust laws if brought pursuant to an unlawful scheme to monopolize. The conduct proscribed in Kobe does not fall within either the traditional sham exception or the proposed revision of the sham exception. The counterdefendants were genuinely attempting to enforce legal claims maintained in good faith. Accordingly, the Kobe doctrine, like Singer, is presently of doubtful validity.

3. Walker Process Equipment, Inc. v. Food Machinery \& Chemical Corp. In Walker Process Equipment, Inc. v. Food Machinery \& Chemical Corp., ${ }^{170}$ the Supreme Court held that enforcement of a fraudulently procured patent may violate section 2 of the Sherman Act. Unlike Singer and Kobe, Walker Process is consistent with the first amendment rationale of California Motor Transport, because the assertion of a claim known to be baseless is not protected by the first amendment. The decision in Walker Process may have important implications that have not been generally recognized. Since the patentee was genuinely attempting to influence the court, the result is difficult to reconcile with the traditional sham excep-

107 See, e.g., Rex Chainbelt, Inc. v. Harco Prods., Inc., 512 F.2d 993 (9th Cir.), cert. denied, 423 U.S. 831 (1975); Kobe, Inc. v. Dempsey Pump Co., 198 F.2d 416 (10th Cir.), cert. denied, 344 U.S. 837 (1952); Handigards, Inc. v. Johnson \& Johnson, 413 F. Supp. 921 (N.D. Cal. 1975).

Itx 198 F.2d 416 (10th Cir. 1952), cert. denied, 344 U.S. 837 (1952).

is" Id. at 424 .

382 U.S. 172 (1965). 
tion. Although the Noerr-Pennington doctrine was not discussed in Walker Process, the case is consistent with the view that attempts to procure anticompetitive governmental action are only exempt from the antitrust laws if the means used are protected by the first amendment. On this view, Walker Process would be authority for subjecting to antitrust liability not only the monopolist who extends his monopoly position by enforcing a fraudulently obtained patent but also the competitor who attempts to achieve the same result by bribing a legislator.

\section{B. The Applicability of the Noerr-Pennington Doctrine When Government Officials Are Alleged to Be Co-Conspirators}

In California Motor Transport the Court stated in dictum that "[c]onspiracy with a licensing authority to eliminate a competitor may also result in an antitrust transgression." "Th The two cases cited in support of this proposition are of questionable authority. Continental Ore Co. $v$. Union Carbide \& Carbon Corp., ${ }^{172}$ the first case cited, did not hold that official participation in a conspiracy deprived defendants of an antitrust exemption under Noerr. Rather, the Court held that the Sherman Act was applicable precisely because the purchasing agent of the Canadian government was not acting as a public official but as the wholly-owned subsidiary of a defendant American corporation. The second case cited by Justice Douglas was a Ninth Circuit decision ${ }^{173}$ that was no longer good law in that circuit. ${ }^{174}$

The lower courts, after California Motor Transport, are split on whether participation by a government official in a conspiracy is sufficient to preclude an antitrust exemption. In Metro Cable Co. v. CATV of Rockford, Inc., ${ }^{175}$ plaintiff alleged that it was denied a cable television franchise because of a conspiracy in which the mayor and an alderman participated. The Seventh Circuit reasoned that an attempt to influence legislative action can succeed only if

171404 U.S. at 513.

172370 U.S. 690 (1962).

${ }^{173}$ Harmon v. Valley Nat'l Bank, 339 F.2d 564 (9th Cir. 1964).

174 See Sun Valley Disposal Co. v. Silver State Disposal Co., 420 F.2d 341 (9th Cir. 1969) (Ninth Circuit refuses to follow its earlier decision in Harmon).

The controversy dates back to Parker v. Brown, 317 U.S. 341 (1943), where the Court pointed out that the case contained "no question of the state or its municipality becoming a participant in a private agreement or combination by others for restraint of trade." Id. at 35152. See generally Comment, Participant Governmental Action Immunity from the Antitrust Laws: Fact or Fiction? 50 TEx. L. Rev. 474 (1974).

17516 F.2d 220 (7th Cir. 1975). 
public officials are persuaded to support the cause and that to deny an antitrust exemption by labeling a persuaded public official a coconspirator would in effect abrogate the Noerr doctrine. ${ }^{178}$ The Third Circuit in Duke \& Co., Inc. v. Foerster ${ }^{177}$ has taken the opposite view. In Duke, plaintiffs alleged that various municipal corporations, private corporations, and a government official conspired to ensure that municipal facilities boycotted plaintiff's products. The defendants contended that the exclusion of plaintiff's products was a result of petitioning activity directed to influence governmental officials. The Third Circuit held that "[w]here the complaint goes beyond mere allegations of official persuasion by anticompetitive lobbying and claims official participation with private individuals in a scheme to restrain trade, the Noerr-Pennington doctrine is inapplicable."178

The position of the Seventh Circuit in Metro Cable is preferable to that of the Third Circuit in Duke and the dictum in California Motor Transport. Acceptance of the co-conspirator theory would mean that although competitors have a constitutional right to petition the government, the right could be lost if the petitioning is successful, because the government officials petitioned might be labeled co-conspirators, and Noerr protection lost. ${ }^{179}$ Although the exception may have some utility in situations such as Continental Ore, where the government official is acting solely to further economic interests, in most cases the co-conspirator exception is unworkable and should not be recognized.

\section{The Applicability of the Noerr-Pennington Doctrine to Attempts to Influence the Government as Purchaser}

One of the most important unresolved questions concerning the Noerr-Pennington doctrine is whether it is applicable to attempts to influence the government acting in a purely commercial capacity. With the government playing an increasingly large role in the nation's economy, ${ }^{180}$ exempting all attempts to influence the government as purchaser from the reach of the antitrust laws would threaten the ability of the market to efficiently allocate resources. Recent studies have shown, for example, that the government is

id Id. at 230.

177 521 F.2d 1277 (3d Cir. 1975).

${ }^{17 x}$ Id. at 1282.

17 See Note, supra note 86, at 856-57 (1968).

${ }^{100}$ Total government purchases amount to approximately 150 billion dollars, about $11 \%$ of the total GNP. See McLachlan, Monopoly and Collusion in Public Procurement: A Survey of Recent American Experience, 8 AntrTRust L. \& Econ. REv. 69, 70 (1976). 
hampered in its procurement programs by various anticompetitive practices of suppliers. ${ }^{181}$ While the government may occasionally use its purchasing power to promote policy objectives such as preferences for small business or minorities, governmental bodies as participants in the economy are more often governed by the same costminimizing incentives as private purchasers. ${ }^{182}$ The question is whether efforts to influence the government in its role as a direct participant in the economy should be treated differently from private commercial conduct where the antitrust laws clearly do apply.

Prima facie, efforts to influence the purchasing decisions of governmental entities or agents acting in a wholly commercial capacity do not seem to be exercises of the right to petition for redress of grievances. In Continental Ore, the antitrust laws were held applicable to a conspiracy that involved "private commercial activity, no element of which involved seeking to procure the passage or enforcement of laws." 183 The Pennington decision, however, suggests the contrary. In that case, the Court held attempts to influence public officials exempt from the antitrust laws even though part of the alleged scheme involved direct attempts to influence the purchasing decisions of the TVA. The implications of Pennington are not entirely clear, however, for it is not apparent from the opinion whether the TVA was acting in a purely commercial capacity.

This apparent inconsistency in the Supreme Court caselaw has led to contradictory results in the lower courts. The NoerrPennington doctrine was given its widest scope in United States $v$. Johns-Manville Corp. ${ }^{184}$ In Johns-Manville, a district court held that an alleged conspiracy to influence municipal government authorities to purchase only pipe with certain specifications, which would have had the effect of excluding foreign pipe from the market, was exempt from the Sherman Act. The court stated that "any concerted activities . . . to influence the decision of public officials on pipe specifications are constitutionally protected and cannot be the basis of a finding of violation of the antitrust laws . . . " 185 The Fifth Circuit reached a similar result in Household Goods Carriers' Bureau v. Terrell. ${ }^{188}$ In this case, defendant's efforts to persuade government agencies not to purchase plaintiff's mileage guide charts were exempt from the antitrust laws.

181 See generally McLachlan, supra note 180.

${ }_{1 \times 2}$ The same reasoning applies when the government is acting as seller.

$1 \times 370$ U.S. at 705.

184259 F. Supp. 440 (E.D. Pa. 1966).

$1 \times 5$ Id. at $452-53$.

Ixs 452 F.2d 152 (5th Cir. 1971) (en banc). 
A contrary result, however, was reached by the First Circuit in George R. Whitten, Jr., Inc. v. Paddock Pool Builders, Inc. ${ }^{187}$ In Whitten, plaintiffs alleged that defendants had conspired to sell their swimming pool products to governmental units by influencing public officials to adopt their specifications for swimming pools. Defendants allegedly used a wide variety of tactics, including misrepresentation about plaintiff's products and pressuring architects hired by public bodies to adopt their specifications. The purchasing decisions were to be made strictly by economic criteria, as required by competitive-bidding statutes. The First Circuit held that defendant's conduct, while not necessarily an antitrust violation, was beyond the scope of the Noerr-Pennington doctrine: "We conclude, therefore, that the immunity for efforts to influence public officials in the enforcement of laws does not extend to efforts to sell products to public officials acting under competitive bidding statutes."188

The approach of the First Circuit represents a desirable limitation on the scope of the Noerr-Pennington doctrine. ${ }^{189}$ Where the government is making purely economic decisions as a consumer in the economy, the Noerr-Pennington doctrine should not provide a shield for anticompetitive behavior. ${ }^{190}$ If the role of the government in an anticompetitive scheme involves no policy determinations-if the governmental unit simply seeks to obtain the most favorable purchasing terms-application of the antitrust laws to such a scheme no more infringes first amendment interests than does the prohibition of anticompetitive conspiracies in the context of private commercial activity.

This is not to say, of course, that all attempts to influence government purchasing agents are unprotected by the first amendment. In light of the Supreme Court's extension of first amendment protection to commercial speech, ${ }^{191}$ activity that consists simply of the accurate presentation of facts relevant to governmental decisions should be immune from antitrust sanction. But the NoerrPennington exemption must be kept distinct from the issue of pro-

187424 F.2d 25 (1st Cir.), cert. denied, 400 U.S. 850 (1970).

ix Id. at 33 . The First Circuit also stated that its holding would not infringe the right to petition because "[t]he First Amendment does not provide the same degree of protection to purely commercial activity that it does to attempts at political persuasion." Id. But see note 121 supra. 1977)

${ }^{1 \times 9}$ See also Kurek v. Pleasure Driveway \& Park Dist., 557 F.2d 580, 592 n.10 (7th Cir.

iso In Georgia v. Evans, 316 U.S. 159 (1942), a pre-Noerr case, the Supreme Court held that the Sherman Act was applicable to a conspiracy to fix prices and suppress competition while selling to a state government.

"'See cases cited in note 121 supra. 
tection for commercial speech. The free speech issues raised by such cases should be treated in the same fashion as those arising in private conspiracies, and must not be avoided by the unwarranted invocation of the Noerr-Pennington exemption.

\section{Joint Efforts to Influence the Adoption of Standards and Rates by Government Agencies}

The antitrust laws limit the freedom of private groups to set industry-wide standards. ${ }^{192}$ The Noerr-Pennington doctrine becomes relevant when private groups attempt to influence the promulgation of standards by the government. In many instances government regulators are highly dependent on the regulated industries for reliable and accurate information. For example, the Federal Water Pollution Act ${ }^{193}$ requires the Environmental Protection Agency to consider the available technology and economic consequences before establishing effluent controls. Representatives of affected industries formed trade associations for the purpose of presenting the EPA with needed comprehensive data. ${ }^{194}$ This need for information has justified many other cooperative arrangements between the government and industry in the setting of standards. ${ }^{195}$

When competitors have attempted to influence agency standards by reporting results of joint research and development, however, antitrust problems have arisen. In United States $v$. Automobile Manufacturers Association, ${ }^{196}$ the Justice Department brought suit against the major automobile manufacturers, charging that they had conspired to delay compliance with automobile emission standards enacted by the state of California. In furtherance of the alleged conspiracy, the manufacturers informed government agencies that they would be unable to comply with state standards by a certain date. Faced with the government suit, the defendants agreed to the entry of a consent decree, which, inter alia, prohibited joint statements to government agencies concerning the feasibility of

"'2 In Radiant Burners, Inc. v. Peoples Gas Light \& Coke Co., 364 U.S. 656 (1961), plaintiff alleged that an industry association created a standard under which gas stoves could obtain a seal of approval. Members of the association were allegedly prohibited from supplying gas to stores that did not bear the seal. The Supreme Court held that restraints flowing from the standard would be unduly restrictive and that a boycott of producers who did not obtain the seal would violate the antitrust laws.

${ }^{133} 33$ U.S.C. $\S 1251$ (1970).

19. See Bakke, Joint Efforts in Developing Standards, 44 ANTitrust L.J. 337, 342-44 (1975).

195 See Bakke, supra note 194, at 337-44; Montgomery, Voluntary Joint Efforts to Solve Energy Problems, 44 ANTITRUsT L.J. 347 (1975).

1981969 Trade Cases If 72,907 (C.D. Cal. 1969). 
complying with a particular standard by a particular time. ${ }^{197}$ The expansive scope of the consent decree in the automobile industry is plainly inconsistent with the Noerr-Pennington doctrine, which recognizes that competitors have a constitutional right to jointly petition the government. ${ }^{198}$

The present case law concerning joint efforts by regulated industries to influence rate structures established by administrative agencies is also unsatisfactory. While some cases have held that such efforts are protected under the Noerr-Pennington doctrine, ${ }^{199}$ one recent case has reached a contrary result. In Motor Carriers Traffic Association, Inc. v. United States, ${ }^{200}$ the Fourth Circuit held that collective rate bureaus, organizations of carriers that jointly propose rate schedules, have no statutory or constitutional right to protest the independent proposals of their member carriers. Although the group of carriers contended that their protests were protected under the Noerr-Pennington doctrine, the court rested its holding on statutory grounds, failing to address the Noerr issue. ${ }^{201}$ Precluding joint action by competitors to influence rates, like the consent decree in the automobile industry, is contrary to the Noerr doctrine. Absent a showing that the carriers collectively set and enforced rate structures or otherwise exceeded the bounds of good faith petitioning, rather than presenting proposals for agency decision, joint efforts to influence rate structures should be protected under Noerr.

197 Moreover the decree has adversely affected other desirable cooperative efforts involving the government and the automobile industry. The Department of Transportation, for example, has requested the assistance of the major automobile manufacturers in determining the feasibility of specific proposals to reduce fuel consumption. Because many of the energysaving proposals being considered by the Department of Transportation involve pollution control devices, the ability of the automobile companies to cooperate with the Department's request by the consent decree is severely restricted. Montgomery, supra note 195, at 353 .

${ }^{198}$ It should be noted, however, that the consent decree was entered before the Supreme Court extended the Noerr-Pennington doctrine to attempt to influence administrative agencies. California Motor Transp. Co. v. Trucking Unlimited, 404 U.S. 508 (1972). For a post-California Motor Transport consent decree which similarly infringes the right of access to the courts, see United States v. Morgan Drive Away, Inc., 1976 Trade Cases \& 60,949 (D.D.C.).

199 E.g., United States v. Southern Motor Carriers Rate Conference, 1977 Trade Cases 1 61,551 (N.D. Ga.).

200559 F.2d 1251 (4th Cir. 1977).

201 Judge Widener dissented on the statutory ground, and therefore expressed no opinion on the carriers' Noerr-Pennington claim. Id. at 1257. 
E. Applicability of the Noerr-Pennington Doctrine to Attempts to Influence Foreign Governments

With the increasing disclosures of corporate lobbying activities abroad, ${ }^{202}$ the question arises whether the Noerr-Pennington doctrine is applicable to attempts to influence foreign governments. ${ }^{203}$ In Continental Ore the Court held that the attempt to influence the Canadian purchasing agent was outside Noerr because the conspiracy involved only private commercial activity. By negative implication, it could be argued that an attempt to influence foreign governments which focused on the passage or enforcement of laws would have been protected, since the Court attached no significance to the fact that a foreign government was involved. ${ }^{204}$

In Occidental Petroleum Corp. v. Buttes Gas \& Oil Co. ${ }^{205}$ however, a district court reached the opposite conclusion. The complaint in Occidental Petroleum alleged that defendants had conspired to prevent plaintiffs from exploiting their offshore oil concessions in the Persian Gulf by inducing foreign governmental interference. Defendants claimed that their activities were protected under Noerr. The court rejected this contention, however, on the ground that there is no first amendment right to petition a foreign government, ${ }^{201}$ and, similarly, the court stated that the concern expressed in Noerr about the need for a representative government to be informed was absent in the international context. ${ }^{207}$

If the Noerr-Pennington doctrine were based on statutory construction of the Sherman Act, the decision in Occidental Petroleum would be hard to justify; it would be difficult to argue that Congress intended attempts to influence our government to be exempt but not similar attempts to influence a foreign government. But once it is recognized that Noerr rests on the first amendment right to peti-

${ }^{202}$ See generally McManis, Questionable Corporate Payments Abroad: An Antitrust Approach, 86 YALE L.J. (1976).

${ }^{203}$ Conduct does not escape the antitrust laws merely because it takes place abroad if there is the requisite effect on American commerce. E.g., Continental Ore Co. v. Union Carbide \& Carbon Corp., 370 U.S. 690, 704 (1962).

${ }^{204}$ See Graziano, Foreign Governmental Compulsion as a Defense in United States Antitrust Law, 7 VA. J. INT'L L. 100, 132 (1967).

${ }^{203} 331$ F. Supp. 92 (C.D. Cal.) aff'd, 461 F.2d 1261 (9th Cir.), cert. denied, 409 U.S. 950 (1971).

${ }^{205}$ Id. at 107-08.

${ }^{20}$ Id. at 108 . The court found, however, that the conduct of the defendants was exempt from the antitrust laws under the act of state doctrine. Under the act of state doctrine, judicial inquiry into the legitimacy of foreign governmental acts is foreclosed. E.g., Banco Nacional de Cuba v. Sabbatino, 376 U.S. 398 (1964). The Supreme Court has recently suggested that the act of state doctrine may not apply to commercial acts of foreign states. Alfred Dunhill of London, Inc. v. Republic of Cuba, 425 U.S. 682 (1976). 
tion, the reasoning of Occidental Petroleum seems persuasive. Since there is no first amendment right to petition a foreign government, attempts to influence such governments should not be protected by the Noerr-Pennington doctrine.

F. Admitting Evidence of Activity Protected By Noerr to Show the Purpose of Other Actions

In Pennington the Court held that activity protected under Noerr "is not illegal, either standing alone or as part of a broader scheme itself violative of the Sherman Act." ${ }^{208}$ In a footnote, however, the Court stated that: "It would of course still be within the province of the trial judge to admit this evidence, if he deemed it probative and not unduly prejudicial . . . [and] if it tends reasonably to show the purpose and character of the particular transactions under scrutiny." ${ }^{209}$ For courts to exercise this right and admit evidence of conduct not itself unlawful to show the anticompetitive purpose of other acts would seriously undermine the protection afforded by Noerr. Most courts have been properly reluctant to admit evidence of conduct lawful under Noerr to show an overall anticompetitive scheme. ${ }^{210}$ In Lamb Enterprises v. Toledo Blade Co. ${ }^{211}$ plaintiff attempted to introduce a letter written by counsel for the defendant ostensibly describing information gathered for presentation to the City Council in an attempt to forestall a competitor from entering the cable television business. The Sixth Circuit held the letter protected under Noerr, and affirmed a lower court's exclusion of the letter as evidence of anticompetitive intent because it would have been highly prejudicial. The first amendment rationale of Noerr suggests that evidence of anticompetitive conduct protected by Noerr should not be admitted to show that related activity was improperly motivated. Admitting evidence of conduct protected under Noerr to prove an antitrust violation, even if accompanied by the dubious protection of a restrictive instruction, would discourage exercise of the constitutional right to petition the government. ${ }^{212}$

2ax 381 U.S. 657,670 (1965).

${ }^{209}$ Id. at $670-71$ n.3.

210 See, e.g., Lamb Enterprises v. Toledo Blade Co., 461 F.2d 506 (6th Cir.), cert. denied, 409 U.S. 1001 (1972); United States v. Johns-Manville Corp., 259 F. Supp. 440, 453 (E.D. $\mathrm{Pa}$. 1966). In cases where evidence of conduct protected under Noerr has been held admissible, courts have tried to minimize its prejudicial effect. See Household Goods Carriers' Bureau v. Terrell, 452 F.2d 152 (5th Cir. 1971) (en banc) (error committed by trial court for failure to give appropriate limiting instruction).

211 461 F.2d 506 (6th Cir.), cert. denied, 409 U.S. 1001 (1972).

212 None of the cases cited by the court in Pennington for the proposition that evidence of legal conduct may be admissible involved constitutionally protected activity. 


\section{ConcLusion}

Application of the Noerr-Pennington doctrine has been fraught with inconsistency because the basis of the doctrine has not been unambiguously articulated by the Supreme Court. This article has argued that the exemption from the antitrust laws established by the Noerr-Pennington line of cases should be limited to conduct protected by the constitutional right to petition the government. The central inquiry is whether the conduct of the defendant asserting a Noerr-Pennington defense merits first amendment protection. General principles for determining whether petitioning activity is constitutionally safeguarded have been proposed, drawing on first amendment doctrines established in the free speech context.

The suggested approach admittedly requires substantial revision of existing law. The sham exception to the Noerr exemption should encompass only constitutionally valueless activity, such as deliberate misrepresentations, bribery, and the knowing assertion of a baseless legal claim. Reformation of an inconsistent body of law necessarily requires that some precedents be overruled and others narrowed. The virtue of the suggested approach is that it affords full and certain protection to first amendment freedoms while preserving the public policy favoring competition embodied in the antitrust laws wherever constitutionally permissible. 